\title{
Spent Brewer's Yeast and Beta-Glucans Isolated from Them as Diet Components Modifying Blood Lipid Metabolism Disturbed by an Atherogenic Diet
}

\author{
Bożena Waszkiewicz-Robak
}

Additional information is available at the end of the chapter

http://dx.doi.org/10.5772/51530

\section{Introduction}

In the report of the Experts of the World Health Organisation and the Food and Agriculture Organisation [1] which reviewed research results concerning the influence of lifestyle, particularly diet components on the risk level of diet-dependent diseases, beta-glucan was acknowledged as a substance limiting the risk of many the so-called civilisation diseases. Simultaneously, it was recognized that the physiological influence of dietary fibre and interactions with other diet components are not fully known, therefore, further research within the scope is reasonable. Among various fractions of dietary fibre, $\beta$-glucans from cereals are especially significant, as they are considered safe and at the same time recommended for intake as food components lowering total cholesterol concentration in blood. Unlike widely-known fractions of dietary fibre, recommended as a factor modifying and preventing the risk of circulatory system and digestive system diseases, beta-glucans show multidirectional and still not entirely recognized health influence [2].

$\beta$-glucans discovered so far have been used in the pharmaceutical industry as substances strengthening the immune system, preparations of antiviral and antibacterial activity, and as natural adjuvants, which resulted in them being called "biological response modifiers" (BRMs). It is assumed that substances of this type cannot do harm, they help the body to adjust to various environmental and biological stresses and have a regulating and multidirected influence on the body, most of all, supporting the immune system, but also showing another positive influence on some functions of the body, e.g. correcting lipid metabolism, correcting glycemic index in people with type 2 diabetes, or exhibiting antitumor activity [3]. 


\section{Sources and general properties of $\beta$-glucans}

$\beta$-glucans are long-chain, multidimensional polymers of glucose, in which particular particles of glucopyranose are linked with glycosidic bonds of $\beta$ type, linearly, in $(1 \rightarrow 3)$ and/or $(1 \rightarrow 4)$ structure or in a branched way, i.e. with side chains of varied length, linked to the main core with glycosidic bonds of $\beta-(1 \rightarrow 6)$ type. They are structural components of plant cell walls (mostly cereals - oats and barley), yeast (Saccharomyces cerevisiae, Saccharomyces fragilis, Candida tropicalis, Candida utilis among others), as well as the socalled Chinese or Japanese fungi. Also beta glucans constituting the components of cell walls, or being the excretion of various bacteria (e.g. Alcaligenes faecalis var. Myxogenes, Cellulomonas flavigena Bacillus or Micromonospora) [4] are known. The presence of $\beta$-glucans have also been confirmed in the cell walls of some vegetables (carrot, radish, soybean) and fruit (bananas) [5].

$\beta$-glucans isolated from fungi seem to be the most advantageous, i.e. of greatest pro-health influence. $\beta$-glucans from cereals are quite well-known. Present interest in isolating $\beta$ glucans takes into account new sources of $\beta$-glucans, e.g. baker's yeast Sacharomyces cerevisiae, considered a better source than cereals or fungi in terms of economics.

The pro-health influence of beta glucans on the body depends on their physicochemical properties. The physicochemical properties of $\beta$-glucans differ depending on characteristics of their primary structure, including linkage type, degree of branching, molecular weight, and conformation (e.g. triple helix, single helix, and random coil structures) $[3,4]$.

Native $\beta$-glucans, depending on their origin contain different bonds, show varied solubility degree and varied direction of pro-health influence. Beta glucans from:

- $\quad$ cereals - containing $(1 \rightarrow 3)-(1 \rightarrow 4)-\beta$ bonds and constituting main soluble fractions, serve as dietary fibre, of a particularly important function aiming to lower cholesterol concentration and triacyloglycerols in blood,

- $\quad$ yeast - containing $(1 \rightarrow 3)-(1 \rightarrow 6)-\beta$ bonds and constituting usually insoluble forms. They are known for their enhancing the immune system, by activating first of all macrofags. They also stimulate the skin cell response to combat free radicals and defend against the environmental pollution, significantly delaying aging process, and act antiinflammatory.

- $\quad$ fungi - contain both $(1 \rightarrow 3) /(1 \rightarrow 6)-\beta$ and $(1 \rightarrow 3) /(1 \rightarrow 4)-\beta$ type bonds, from which $53-83 \%$ constitute insoluble fractions and $16-46 \%$ - soluble fractions. They are called heteroglucans showing universal immunostimulating and immunomodulating activity of antiviral, antibacterial and antiallergic character. They also have the ability to lower high blood cholesterol, inhibit excessive cholesterol synthesis and remove the excess of glucose from peripheral blood. Beta glucan activity as an anti-tumour factor concerns mostly $(1 \rightarrow 3)-(1 \rightarrow 6)-\beta$ forms.

A lower level of branching and lower polymerisation degree are characterised by better solubility (Fig. 1). It is believed that insoluble $\beta$-glucans are those whose degree of 
polymerisation (DP) is higher than 100 [6]. Insoluble or slightly soluble beta glucans contain very long, multi-branched side chains in the particle (Fig. 2).

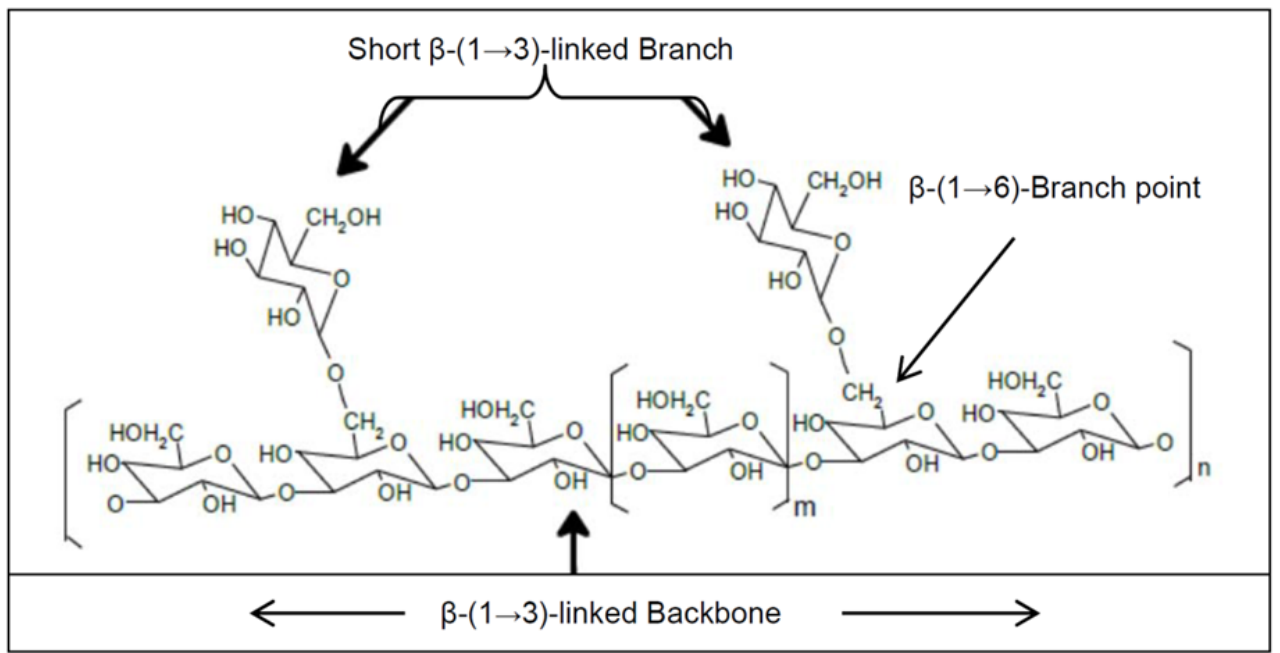

Figure 1. An example of the molecular structure of soluble yeast $\beta$-glucan.

Molecular weight of beta glucans obtained from various sources differs within a wide range of values from $0,2 \times 10^{1} \mathrm{kDa}$ to $4 \times 10^{4} \mathrm{kDa}$. From technological point of view, beta glucans of high molecular weight $\left(>3 \times 10^{3} \mathrm{kDa}\right.$ ) are characterised by high viscosity, and those of low molecular weight (about $9 \mathrm{kDa}$ ) constitute gels. Hydrolysed beta-glucans are soluble, but not very viscous and do not constitute gels.

Physicochemical properties of $\beta$-glucans might be modified through the use of various technologies during their isolation. Used chemical or enzymatic methods, leading to the hydrolysis of long-chain $\beta$-glucans, allow to lower the degree of depolymerisation and their particle mass in relation to native form, which simultaneously increases their solubility and lowers viscosity in liquids [7].

Among many methods leading to depolymerisation of long-chained and multi-branched $\beta$ glucans, it is essential to distinguish other chemical modifications, e.g. esterification [8], phosphorylation [9], sulphonation [10], chlorosulphonation [11], or carboxylmethylation [12]. This last method is considered to be one of the most effective methods transforming insoluble forms into soluble fractions [13]. All authors state, however, that introducing an additional functional group to $\beta$-glucan chain might lead to simultaneous growth of glucan particle size, which in turn leads to excessive increase in their viscosity in water solution, and therefore, shows different than expected physiological influence [14]. There is also research published showing that viscosity of $\beta$-gluccans depends to a large extent on the degree of purification during their isolation [15]. 


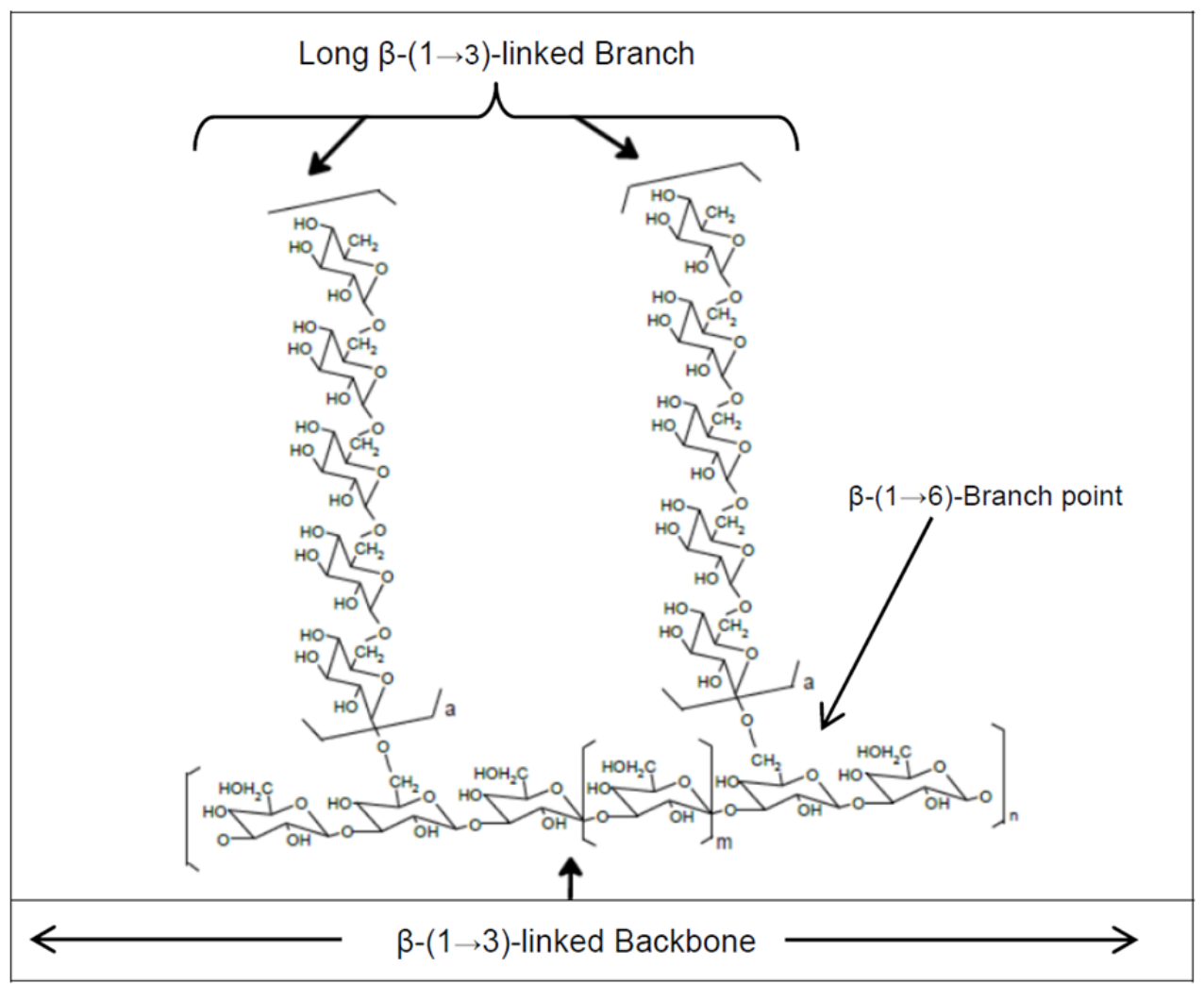

Figure 2. An example of the molecular structure of insoluble yeast $\beta$-glucan.

\section{1. $\beta$-glucans isolated from cereals}

Among cereals, the greatest amount of $\beta$-glucan in relations to dry mass can be found in barley grains (3-11\%) and oat grains (3-7\%). Small quantities of $\beta$-glucans are also found in rice (about $2 \%$ ), wheat (about $1 \%$ ) and sorghum (0.2-0.5\%) [11]. In case of oat, $\beta$-glucans are present mostly in external layers of the grain, whilst in barley grain, these substances are spread evenly in the entire grain.

Unlike insoluble cellulose, whose glucose particles are linked linearly with $\beta$-D- $(1 \rightarrow 4)$ bonds, $\beta$-glucans contained in the endosperm of cereals grains are the mixture of $\beta$-Dglucose unbranched chains linked with $\beta-(1 \rightarrow 3)$ and $\beta-(1 \rightarrow 4)$ glycosidic bonds (Fig. 3) [16].

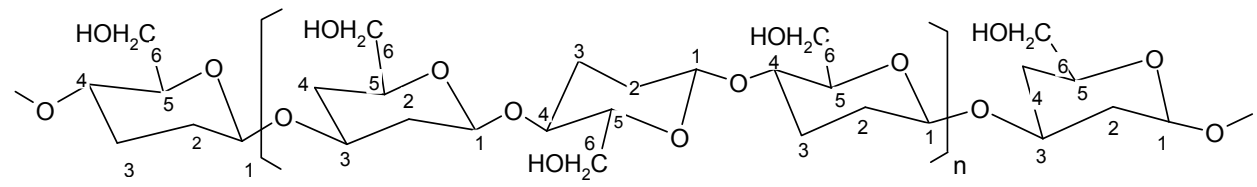

Figure 3. Primary molecular structure of (1-3)/(1-4)- $\beta$-glucan from barley grain. 
Slightly different properties are characteristic of $\beta$-glucans isolated from sorghum, in which all three types of chains, i.e. both $\beta-(1 \rightarrow 3)-, \beta-(1 \rightarrow 4)-$, and $\beta-(1 \rightarrow 6)$ [17] have been found. In $\beta$-glucans isolated from most cereals $\beta$ - $(1 \rightarrow 3)$ bonds constitute about $30 \%$, whilst $\beta$ - $(1 \rightarrow 4)$ bonds - about $70 \%$ of all bonds, with slight deviations characteristic of particular cereals [18].

$\beta$-glucans from oat are known as substances of pro-health influence comparable to $\beta$ glucans isolated from barley [19], particularly in the ability to lower glucose concentration in blood [20], total cholesterol and triacylglycerols in blood [21,22].

$\beta$-glucans extracted from cereals, which mainly contain $\beta$-(1,3-1,4)-d-glucan, have been demonstrated to reduce blood lipid levels, including cholesterol and triacylglycerols levels. The mechanisms by which $\beta$-glucans from cereals reduce blood lipid levels have been shown to include prevention of cholesterol reabsorption by adsorption, elimination of bile acid by adsorption, an increase in bile acid synthesis, and suppression of hepatic cholesterol biosynthesis by short-chain fatty acids produced by fermentation with intestinal bacteria $[23,24]$.

\section{2. $\beta$-glucans isolated from fungi}

There are "medicinal" fungi, used in traditional medicine of the countries of the East [25], such as Chinese Reishi (Ganoderma lucidum), or Japanese Shiitake (Lentinula edodes) and Maitake (Grifola frondosa), arboreal fungi: Chaga (Inonotus obliquus), Turkey Tail (Trametes versicolor), Split Gill (Schizophyllum commune), Mulberry Yellow Polypore (Phellinus linteus) and cultivated, e.g. Hiratake (Pleurotus ostreatus, Oyster mushroom). The concentration of $\beta$ glucans in Basidiomycota fungi is relatively low and ranges from 0.21 to $0.53 \mathrm{~g} / 100 \mathrm{~g}$ of dry mass [26].

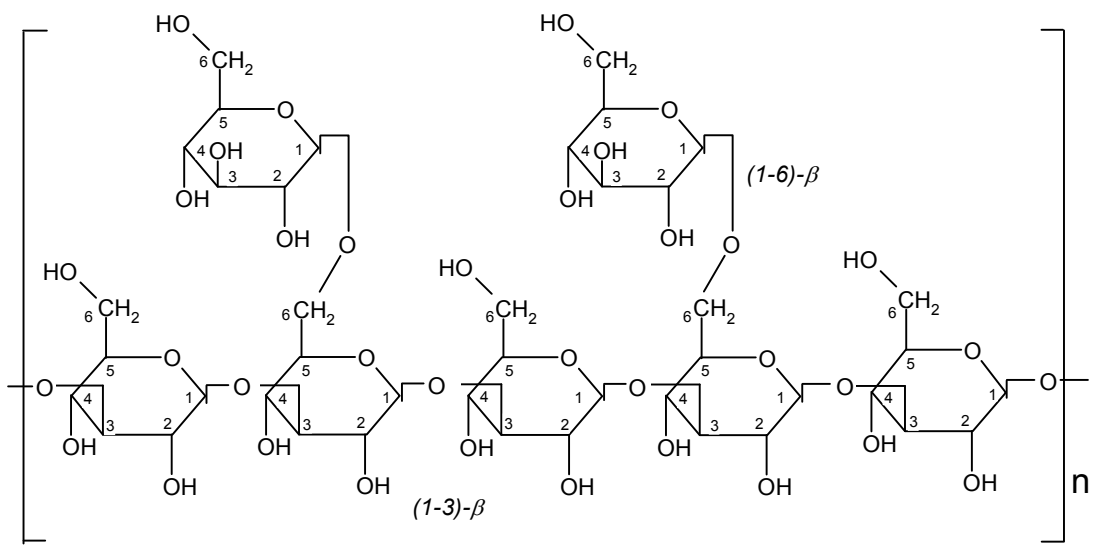

Figure 4. Primary molecular structure of lentinan from Lentinus edodes.

$\beta$-glucans isolated from fungi are heteroglucans containing both $(1 \rightarrow 3) /(1 \rightarrow 4)-\beta$ and $(1 \rightarrow 3) /(1 \rightarrow 6)-\beta$ bonds. They usually constitute the mixture of insoluble (about $53-83 \%$ 
participation) and soluble (about 16-46\%) fractions [40] of varied properties. They are mostly known as factors stimulating the immune system, having antiviral, antimicrobial and antiallergic properties $[27,28]$. They also have the ability to lower high blood pressure, slow down the excessive cholesterol synthesis and lower glucose concentration in blood [29], as well as show antioxidating properties [23]. They are also known as substances of antitumour properties [4]. $\beta$-glucans well-known in terms of structure and biological activity are identified in accordance with their names, e.g.: lentinan (Fig. 4) obtained from Lentinus edodes, schizophyllan (SPG) (Fig. 5A) from Schizophyllum commune, pleuran from Pleurotus ostreatus or pullulans (AP-FBG) (Fig. 5B) from Aureobasidium pullulans, scleroglucan (SGG) (Fig. 6) from Sclerotium rolfsii, grifolan (GRN) from Grifola frondosa, krestin (PSK polysaccharide-K and PSP - polysaccharopeptide) from Coriolus versicolor [30-34].

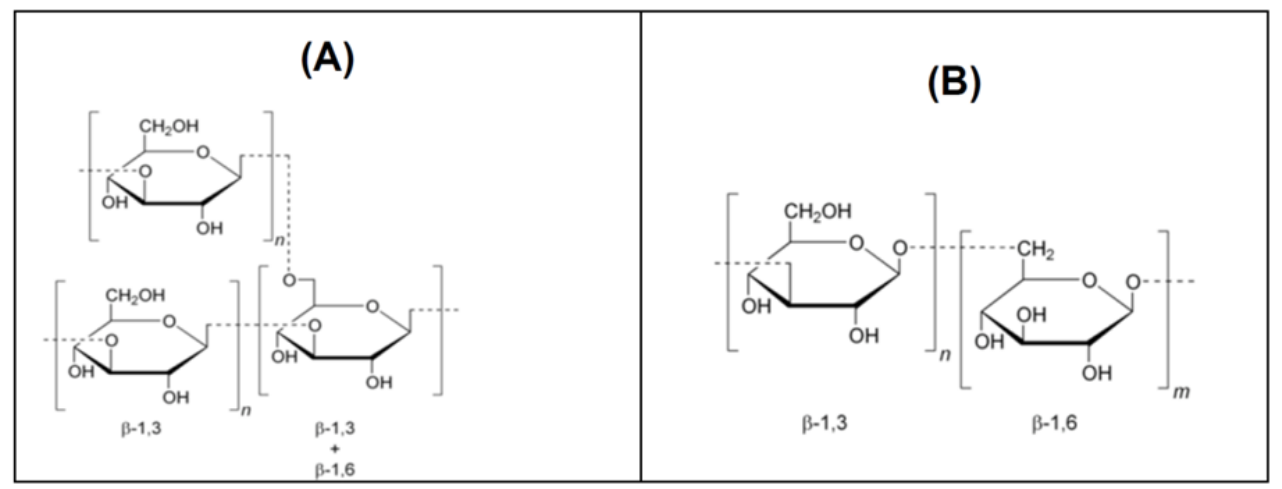

Figure 5. Primary molecular structure of Schizophyllan (A) from Schizophyllum commune and pleuran (B) from Aureobasidium pullulans.

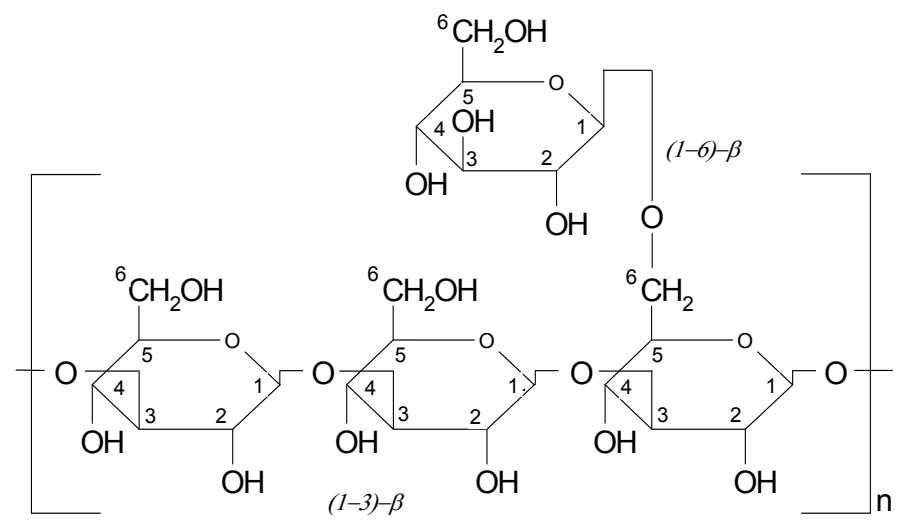

Figure 6. Primary molecular structure of scleroglucan from Sclerotium rolfsii.

Recently characterized structure of a novel water-soluble polysaccharide (ZPS - Zhuling polysaccharide) from the fruit bodies of medicinal mushroom Polyporus umbellatus and investigate its immunobiological function [35]. 


\section{3. $\beta$-glucans isolated from bacteria}

Polysaccharides of bacterial origin are known and widely used in food industry mostly as additives. They are often called bacterial egzopolisaccharides and constitute the ingredient of the cell wall, or can be excretions of various microorganisms, such as: Cellulomonas flavigena of KU strain [36], Bacillus curdlanolyticus and Bacillus kobensis [37], Bacillus and Micromonospora [38] Agrobacterium spp. ATCC31749 [39], Bradyrhizobium, Rhizobium spp. Sarcina ventriculi [40].

The ones mass produced and used are: xanthan, dextran, pullulan or gellan. $\beta$-glucans of bacterial origin have the structure similar to mannans, but glucose constitutes their basic unit building block. Mucilages called xanthans produced by Xanthomonas campestris bacteria pathogenic for plants are widely used. Beta glucans produced as a result of microbiological fermentation called curdlan (Fig. 7) and laminarin are known from technological point of view.

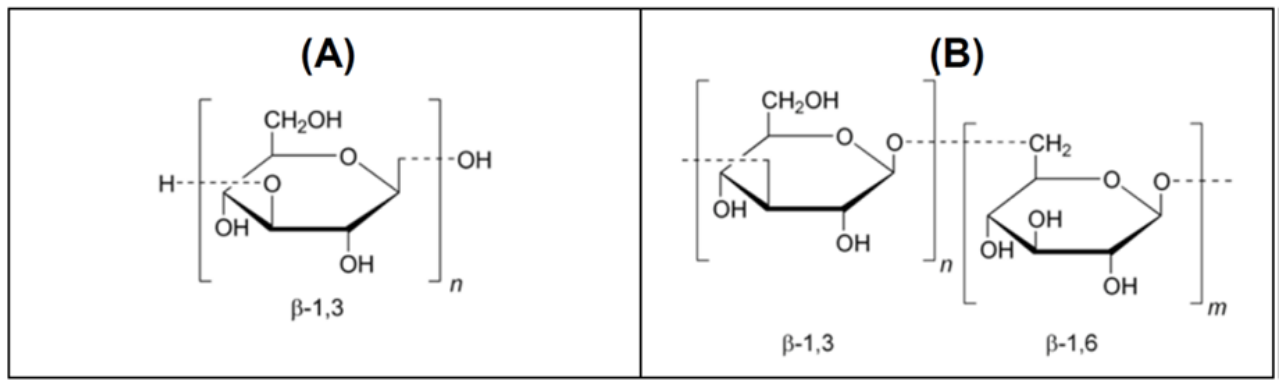

Figure 7. Primary molecular structure of (1-3)- $\beta$-glukan (A - curdlan; B - laminarin).

Dextran is a glucan synthesized from saccharose by Leuconostoc mesenteroides and Streptococcus, containing glucose particles connected most often with $(1 \rightarrow 6)$ bonds of $\alpha$ type [41].

Microorganisms used in food industry, mostly lactid acid bacteria (LAB) are a rich source of egzopolisaccharides [42].

\section{4. $\beta$-glucans isolated from Saccharomyces cerevisiae}

Yeast, both baker's and spent brewer's yeast, are characterised by high concentration of beta glucans, amounting on average to $7.7 \%$, located in the cell wall. Cell wall (constituting 15$30 \%$ of dry mass of yeast cells), is a complex, multi-particle structure, consisting in $50-60 \%$ of $\beta$-glucans and in about $40 \%$ of mannoproteins. Natural $\beta$-glucans isolated from yeast are insoluble in water, and their insolubility is caused by chitin, a polisaccharid consisting of residues of $\mathrm{N}$-acetyl-glucosamine, linked with $(1 \rightarrow 4)-\beta$-glycosidic bonds (chitin amounts to about $1 \%$ of cell wall mass). Chitin complex-(1 $\rightarrow 3)-\beta$-glucan (about $3-9 \%$ of cell wall mass), is located on the inside of cell wall $(1 \rightarrow 6)-\beta \beta$-glucan branches, link particular components of cell wall with the use of mannoproteins and covalent bonds. Mannoproteins are located on the outside of yeast cell wall [43]. 
Sparse research on $\beta$-glucans isolated in the laboratory from cell walls of baker's yeast Saccharomyces cerevisiae, shows varied biological activity depending on the used technology of their isolation. They can strengthen the immune system, show antioxidant properties, and delay the process of cell aging [23,44].

Due to a high content of $\beta$-glucans in spent brewer's yeast Saccharomyces cerevisiae, remaining after alcohol fermentation in the process of beer production, it seems that they can be an effective and inexpensive material for obtaining $\beta$-glucan preparations.

Fig. 8 presents the diagram showing the use of spent brewer's yeast, which constitute troublesome waste for the brewing industry.

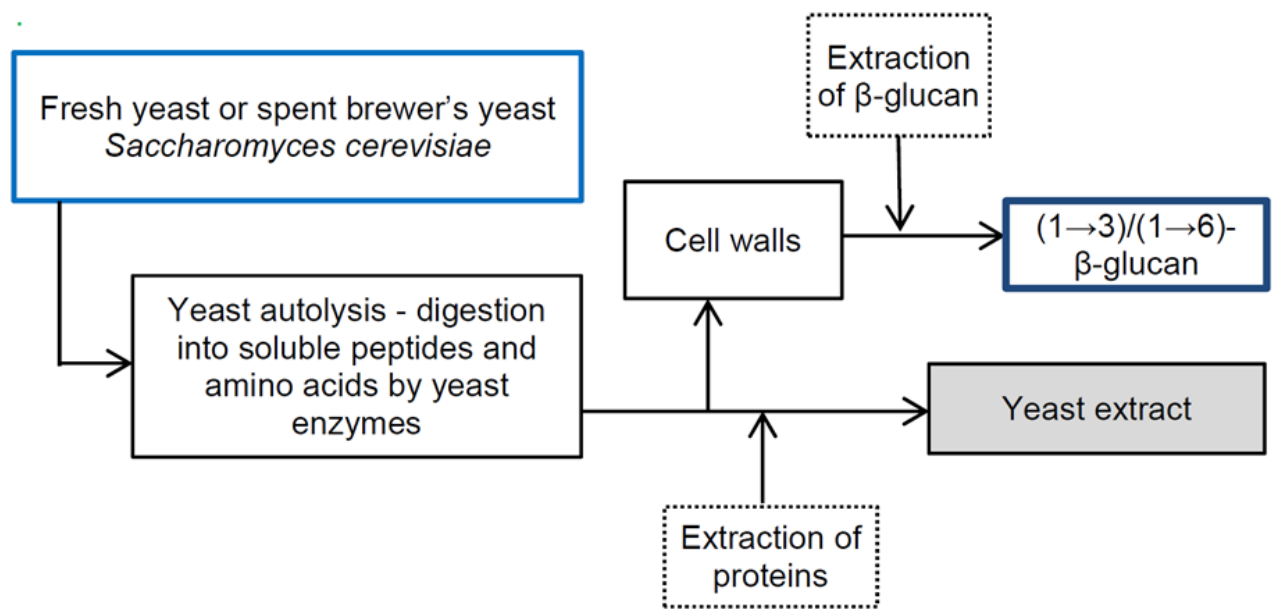

Figure 8. The possibilities of using spent brewer's yeast Saccharomyces cerevisiae.

Beta glucans might be obtained as a byproduct in the production of preparations enhancing flavour (yeast extracts), and the remains after fibre extraction constitute a good material for obtaining beta glucans.

So far no research has been conducted on pro-health $\beta$-glucans obtained from spent brewer's yeast Saccharomyces cerevisiae, which constitute a natural, often a troublesome byproduct of the brewing industry, waste product after alcohol fermentation in beer production. Sparse research on $\beta$-glucans obtained from this type of material is conducted on a laboratory scale and aims mostly to examine their technological properties, conditioning their usage as additional substances of thickening, gelling and/or water binding properties.

\section{The purpose and scope of work}

This work has aimed to assess pro-health activity of $\beta$-glucans isolated from a new, uninvestigated within this scope source, i.e. spent brewer's yeast Saccharomyces cerevisiae. 
Functional properties, i.e. physico-chemical properties of dried spent brewer's yeast and $\beta$ glucans isolated from them have been characterized. In order to determine the influence of glucan preparations (soluble BG-CMG and native - insoluble BG-HP) and spent brewer's yeast on the lipid metabolism of the rat body, examined preparations have been added to atherogenic diet of animals ( $1 \%$ of cholesterol and $20 \%$ of fat) in such an amount so as to obtain the following levels:

a. for $\beta$-glucans: 10 and $100 \mathrm{mg} / \mathrm{kg}$ of body mass - the dose of $10 \mathrm{mg} / \mathrm{kg}$ body mass is the amount calculated for an adult weighing $70 \mathrm{~kg}-700 \mathrm{mg}$ per day, the dose $100 \mathrm{mg} / \mathrm{kg}$ body mass -7 g per day,

b. Spent brewer's yeast were added in the amount $100 \mathrm{mg}$ daily $(0.5 \%$ of diet components, which is about $500 \mathrm{mg} / \mathrm{kg}$ body weight). This amount corresponded to the intake of beta-glucans from spent brewer's yeast in an amount of $10 \mathrm{mg} / \mathrm{kg}$ body weight.

The research has been conducted in relation to control group, which has not been given yeast preparation additive.

\section{Research material and conditions of biological experiment}

Material consisted of:

- dried, spent brewer's yeast Saccharomyces cerevisiae - from INTER YEAST company, constituted the research material (Content: Protein - 43.5\%, fat - $4 \%$ Total Carbohydrates - $25 \%$, squalene $-125 \mathrm{mg}$ per $100 \mathrm{~g}$ of powder, beta-glucan $-1.9 \%$ ),

- commercial, pure beta glucans isolated from spent brewer's yeast (from the yeast cell walls): insoluble BG-HP (Beta HP(1/3)-(1/6)- $\beta$-D-Glucane Powder),

- and soluble carboxymethylglucan BG-CMG (Beta CMG: 92\% $\beta-1,3 / 1,6-D-$ glucan concentration, $1.2 \%$ protein, $<0.6 \%$ of mannans and $<0.5 \%$ chitin), were provided by German company LEIBER GmbH - INTER YEAST.

\subsection{Biological experiment and its progress}

The experimental animals were growing male rats (Wistar) with an initial body weight of about $100 \mathrm{~g}$. Prior to the start of the experiment, animals were given water and commercial, standard rat food LSM ${ }^{\circledR}$ ad libitum for 7 days to adapt them to the experimental conditions. Later the animals were randomly divided into 6 groups (7 rats in one group) in relation with diet composition:

a. Control - without $\beta$-glucans,

b. BG-CMG - with carboxymethylglucan:

- $\quad$ BG-CMG10 (10 mg/kg of body mass),

- $\quad$ BG-CMG100, (100 mg/kg of body mass),

c. BG-HP - with insoluble beta glucan:

- $\quad$ BG-HP10 $(10 \mathrm{mg} / \mathrm{kg}$ of body mass),

- $\quad$ BG-HP100 $(100 \mathrm{mg} / \mathrm{kg}$ of body mass),

d. and SBY - with dried spent brewer's yeast. 
The average body mass of rats in each group was similar. Diets (semisynthetic, isocaloric) were prepared in accordance with the recommendations of the American Institute of Nutrition [45]. Mineral mixture AIN-93G-MX and vitamin mixture AIN-93G-MV were used. The composition of experimental diets is presented in Table 1.

The research was conducted on control group, which did not receive beta glucan additive. Diet intake and body weight growth of research animals were controlled during the research. Ethics Committee approved of the research. Energy derived from fat, protein and carbohydrates was $40.1 ; 15.8$ and $44.1 \%$, respectively.

\begin{tabular}{|c|c|c|c|c|c|c|}
\hline \multirow[b]{2}{*}{ Components } & \multicolumn{6}{|c|}{ Diet } \\
\hline & Control & $\begin{array}{c}\text { BG- } \\
\mathrm{CMG}_{10}\end{array}$ & $\begin{array}{c}\text { BG- } \\
\text { CMG100 }\end{array}$ & $\mathrm{BG}-\mathrm{HP}_{10}$ & BG-HP100 & $\mathrm{SBY}_{100}$ \\
\hline Wheat starch, g & 49.0 & 49.0 & 49.0 & 49.0 & 49.0 & 48.5 \\
\hline Casein, $\mathrm{g}$ & 20.0 & 20.0 & 20.0 & 20.0 & 20.0 & 20.0 \\
\hline Soya oil, $\mathrm{g}$ & 20.0 & 20.0 & 20.0 & 20.0 & 20.0 & 20.0 \\
\hline$\alpha$-cellulose, $\mathrm{g}$ & 5.0 & 5.0 & 5.0 & 5.0 & 5.0 & 5.0 \\
\hline DL-methionine, $\mathrm{g}$ & 0.3 & 0.3 & 0.3 & 0.3 & 0.3 & 0.3 \\
\hline Choline bitartrate, $\mathrm{g}$ & 0.2 & 0.2 & 0.2 & 0.2 & 0.2 & 0.2 \\
\hline Mineral mix, $\mathrm{g}$ & 3.5 & 3.5 & 3.5 & 3.5 & 3.5 & 3.5 \\
\hline Vitamin mix, g & 1.0 & 1.0 & 1.0 & 1.0 & 1.0 & 1.0 \\
\hline Cholesterola/, g & 1.0 & 1.0 & 1.0 & 1.0 & 1.0 & 1.0 \\
\hline Spent brewer's yeast, $g$ & 0 & 0 & 0 & 0 & 0 & 0,5 \\
\hline $\begin{array}{l}\beta \text {-glucans from spent } \\
\text { brewer's yeast, } \mathrm{mg} / \mathrm{kg} \\
\text { of body mass/day }{ }^{\mathrm{b}} \text { : }\end{array}$ & 0 & 10 & 100 & 10 & 100 & 0 \\
\hline $\begin{array}{l}\text { Protein, } g / 100 \mathrm{~g} \text { of diet } \\
(\% \text { of } \mathrm{EV})\end{array}$ & \multicolumn{5}{|c|}{$18.0(15.8 \%)$} & $18.1(15.9)$ \\
\hline $\begin{array}{l}\text { Fat, } g / 100 \mathrm{~g} \text { of diet } \\
(\% \text { of } \mathrm{EV})\end{array}$ & \multicolumn{5}{|c|}{$20.3(40.1 \%)$} & $20.3(40.2)$ \\
\hline $\begin{array}{l}\text { Carbohydrates, } \mathrm{g} / 100 \mathrm{~g} \\
\text { of diet (\% of EV) }\end{array}$ & \multicolumn{5}{|c|}{$50.2(44.1 \%)$} & $49.9(43.9)$ \\
\hline $\begin{array}{l}\text { Energy value (EV), } \\
\text { kJ (kcal) }\end{array}$ & \multicolumn{5}{|c|}{$1904(455,5)$} & $1900.5(454.7)$ \\
\hline
\end{tabular}

Table 1. Composition of $100 \mathrm{~g}$ control and model diet enriched with $\beta$-glucans.

a/ Sample weight of prepared earlier diet were mixed with fresh cholesterol in the proportion 99:1, directly before being served to animals; $b / \beta$-glucans were weighed in the amounts adequate for each rat's body mass, then mixed with small diet portions $(5 \mathrm{~g})$ and given to each animal individually. After having eaten, the animals were served diet and water ad libitum.

During the whole experimental period (6 weeks) rats were housed in individual cages with $24 \mathrm{~h}$ access to water. The premises, in which the experimental rats were housed had a 12:12h light cycle with temperature of $21-22^{\circ} \mathrm{C}$ and humidity of $55-65 \%$. The proper experiment 
lasted 6 weeks, after which blood from myocardium was collected. Animals were put to sleep with the peritoneal injection of Thiopental.

\subsection{Research methods}

\subsubsection{Particle size and swelling ability}

The size of particles was analysed with the method of laser difraction with the use of Mastersizer S analyser of Malvern Instruments Ltd., Malvern, Great Britain. Particle size distribution of examined preparations was measured using the wet process in oil emulsions and/or water solutions of concentration within the range of $0.01-0.05 \%$.

\subsubsection{Viscosity of water solutions}

Rheometric measurements were conducted with the use of rheo-viscometer of Brookfield DV III+ using ULA spindle and DIN-82. Measurement device was coupled with RHEOCALC for Windows version 2.l. computer programme, from which dynamic viscovity values were read at varied shear velocity.

\subsubsection{Antioxidant properties of preparations with in vitro method}

Antioxidant properties of preparations were marked with spectrophotometric method with the use of synthetic radicals ABTS ${ }^{\bullet+}$ [46]. Antioxidant activity of examined preparations was expressed as the ability of an examined preparation to de-activation of cation radicals ABTS $^{\bullet+}$ and as TEAC (Trolox Equivalent Antioxidant Capacity), i.e. $\mu \mathrm{M}$ of Trolox for $1 \mathrm{~g}$ of preparation.

\subsubsection{Lipid content}

Total lipid content was marked with a modified method of Folch et al. [47].

Total cholesterol - methyl esters have been prepared, from which $0.5 \%$ of the solution has been made using toluene as solvent. $1 \mu \mathrm{l}$ was collected from prepared solutions, which was dosed with a $\mu$-syringe on the Hewelett-Packard HP 6890 Series GC System Plus gas chromatographer with a flame ionization detector (FID) and capilary column with polar stationary phase of $30 \mathrm{~m}$ length. Stigmasterol produced by Sigma was used as a standard.

Lipid fractions - particular lipid fractions: HDL-cholesterol, and triacylglycerols (TG) in the plasma (mmol/L) were enzymatically measured with INTEGRA analyser. The concentrations of LDL cholesterol $(\mathrm{mg} / \mathrm{dL})$ were calculated as LDL cholesterol $=$ total cholesterol - HDL cholesterol - (triacylglycerols/5). Cholesterol was converted from mg/dL to $\mathrm{mmol} / \mathrm{L}$ by multiplying by 0.0259 . VLDL-cholesterol was calculated as $1 / 5 \mathrm{TG}$ [48]. In order to calculate the amount of cholesterol expressed in $\mathrm{mg} / \mathrm{dl}$ for $\mathrm{mmol} / \mathrm{l}, 0.0258$ multiplier was used. 
Atherogenic index - atherogenic index was calculated as the relation of assessed lipid fraction (HDL-Chol or LDL-Chol) to total cholesterol content (Total-Chol). This index allowed for defining the changes of these fraction participation in relation to total cholesterol content.

\subsubsection{Statistical analysis}

Data is presented as means \pm standard deviation (SD). Obtained results were statistically analysed with STATGRAPHIC programme for Windows (v. 4.1.). The data was analysed using one-way analysis of variance (ANOVA). When a significant $\mathrm{F}$ ratio was found, Tukey's multiple-comparison tests were conducted. Differences were considered significant at $\mathrm{P}<0.05$.

\section{Results and discussion}

\subsection{Characteristics of physico-chemical properties of used preparations}

Preparations of pure $\beta$-glucans and the preparation of dried spent brewer's yeast examined in this work have proven to be efficient in correcting blood lipid metabolism, which has been shown in biological experiment on rats, which were given atherogenic diet, containing $20 \%$ of fat and $1 \%$ of cholesterol, and at the same time preparations of beta glucans: soluble (BG-CMG) and insoluble (BG-HP) or dried, spent brewer's yeast (SBY).

These preparations differed in physico-chemical properties, i.e. particle size, solubility, the ability of water absorption and viscosity. These properties had a significant influence on the final effects obtained after their use in the experiment.

During the examination of distribution of particle size of powdered $\beta$-glucans in comparison with spent brewer's yeast preparations, it has been established that BG-HP preparation contained $60 \%$ of all particles of $59.4 \mu \mathrm{m}$ in diameter and only about $5 \%$ of about $5 \mu \mathrm{m}$ in diameter. The preparation of soluble $\beta$-glucan BG-CMG contained at least three clusters of particles of varied size, i.e. appropriately $0.2 \mu \mathrm{m}, 3.5 \mu \mathrm{m}$ and $90.2 \mu \mathrm{m}$, whereas the majority of particles (about $20 \%$ of all) had a diameter of $90.2 \mu \mathrm{m}$. Dried spent brewer's yeast were characterised by three groups of varied size, and their greatest share (over $40 \%$ ) had the size of about $63.6 \mu \mathrm{m}$. Dried spent brewer's yeast particles were similar in size to particles of $\beta$ glucan BG-HP preparation.

Table 2 presents the percentage cumulated participation of particles in preparation content (e.g. $d_{5}$ means that $5 \%$ of particles has the size below the value shown in the table, $d_{50}=50 \%$ of particles has the size not exceeding the value presented in the table, etc.).

Particles of all examined preparations absorbed water during hydration. Preparation of native $\beta$-glucan BG-HP from brewer's yeast and dried spent brewer's yeast did not dissolve or dissolved only partially creating unstable water solutions with the tendency to create residue. Water solutions of $\beta$-glucan BG-CMG preparations were very viscid (65.2 $\mathrm{mPas}$ for 
$1 \%$ water solution and $574.9 \mathrm{mPas}$ for $3 \%$ solution), whereas the preparations of $\beta$-glucan HP preparations and dried spent brewer's yeast, dissolved in water only partially, creating nonviscid or only slightly viscid solutions (0.4-1.4 mPas) - tab. 3.

\begin{tabular}{|l|c|c|c|c|c|c|c|c|}
\hline Preparations & \multicolumn{7}{|c|}{ The size of particles in cumulated values $(\mathrm{d})[\mu \mathrm{m}]$} & \multirow{2}{*}{$\mathrm{X}_{\text {ś. }}[\mu \mathrm{m}]$} \\
\cline { 1 - 8 } & $\mathrm{d}_{5}$ & $\mathrm{~d}_{10}$ & $\mathrm{~d}_{25}$ & $\mathrm{~d}_{50}$ & $\mathrm{~d}_{75}$ & $\mathrm{~d}_{90}$ & $\mathrm{~d}_{95}$ & \\
\hline HP $\beta$-glucan & 5.2 & 16.8 & 32.7 & 50.14 & 70.74 & 93.4 & 107.3 & 52.98 \\
\hline CM $\beta$-glucan & 0.2 & 0.48 & 2.24 & 17.0 & 67.7 & 133.6 & 174.6 & 44.62 \\
\hline SBY & 6.61 & 16.26 & 34.8 & 64.5 & 169.5 & 325 & 396.9 & 119.4 \\
\hline
\end{tabular}

Table 2. The comparison of cumulated distribution of particle size of examined $\beta$-glucans and powdered spent brewer's yeast.

$\beta$-glucan particles isolated from spent brewer's yeast, in the initial phase of hydration increased their volume from 3 (soluble BG-CMG) to about 5 times (insoluble BG-HP). These glucans were characterised by the fact that in the final stage of hydration, these particles decreased. The increasing, and then decreasing sizes of particles in the initial stage of hydration, may constitute the proof of tearing hydrogen and covalency bindings of helix of pre-hydrated $\beta$-glucans.

\begin{tabular}{|l|c|c|c|c|}
\hline \multirow{2}{*}{ Preparation } & \multicolumn{2}{|c|}{$\begin{array}{c}\text { Viscosity for 10 RPM } \\
{[\mathrm{mPas}]}\end{array}$} & \multicolumn{2}{c|}{$\begin{array}{c}\text { The level of adjustment } \\
\text { reliance [\%] }\end{array}$} \\
\cline { 2 - 5 } & $1 \%$ & $3 \%$ & $1 \%$ & $3 \%$ \\
\hline$\beta$-glucan BG-CMG & $65.2^{\mathrm{a}} \pm 7.5$ & $574.9^{\mathrm{a}} \pm 36.3$ & $96.0 \pm 2.1$ & $94.4 \pm 4.7$ \\
\hline$\beta$-glucan BG-HP & $1.4^{\mathrm{c}} \pm 0.2$ & $1.9^{\mathrm{c}} \pm 0.1$ & $90.0 \pm 1.3$ & $93.6 \pm 0.9$ \\
\hline SBY & $0.4^{\mathrm{d}} \pm 0.04$ & $1.5^{\mathrm{d}} \pm 0.04$ & $84.6 \pm 4.7$ & $90.9 \pm 1.6$ \\
\hline
\end{tabular}

Table 3. The characteristics of viscosity $\mathrm{a}$ of $1 \%$ and $3 \%$ water solutions of $\beta$-glucan preparations in comparison with $1 \%$ and $3 \%$ viscosity of water solutions of spent brewer's yeast.

a/ identical letter signs in columns equal the lack of a significant difference between compared mean values

Limited solubility in water of native $\beta$-glucan HP might be explained with the presence in the structure of long, side chains with bindings $\beta-(1 \rightarrow 6)$, which can cause high crystality and insolubility of this $\beta$-glucan [6].

Weak hydration of complex structure of helix of high molecular weight $\beta$-glucans is the reason for their mutual intermolecular interactions between $\beta-(1 \rightarrow 3)-D$ and $\beta-(1 \rightarrow 6)-D-$ glucan bindings, of strenght exceeding the interactions between bindings of $\beta$-glucan and water particle bindings or another solvent. Lowering of degree of polymerisation of beta glucans with $\beta$ - $(1 \rightarrow 3) /(1 \rightarrow 6)$-D-glucan bindings to DP below 20 , results in the weakening of intermolecular interactions, therefore, creating new bindings between $\beta$-glucan particles and solvent, causing its dissolution [2,4].

The apparent improvement of $\beta$-glucan solubility in water solutions, without polymer degradation, can be achieved by activities stabilizing their scattering in water environment. [49]. It is possible to achieve stable scattering of $\beta$-glucans in water solutions, e.g. through 
microwave heating, with temperature range $100-121^{\circ} \mathrm{C}$ and increased pressure within $4-10$ min. Quite advantageous effects in the modification of physico-chemical properties of $\beta$ glucans are also obtained while using ultrasounds, as the method does not change the chemical structure of polymer's particle size, resulting only in the decrease in the particle size, through breaking of the most sensitive chemical bindings. This method is used to obtain the so-called micronized $\beta$-glucan preparations. The process of micronization improves the distribution and stability of slightly soluble powders in water environment. The method also leads to permanent reduction of solution viscosity. According to the definition in the Polish Pharmacopoeia, micronized powders should contain particles of average diameter below $10 \mu \mathrm{m}$, at admissible $20 \%$ particle content of up to $50 \mu \mathrm{m}$ diameter.

CMG $\beta$-glucan preparation of modified chemical properties is the example of $\beta$-glucan examined in this work. HP native beta-glucan obtained from spent brewer's yeast underwent the process of carboxymethylation, and in turn led to obtaining BG-CMG $\beta$-glucan preparation of modified viscosity, dozen times higher than the viscosity of HP native $\beta$-glucan (tab. 3).

Carboxymethylated $\beta$-glucan CMG strongly absorbed water creating solutions of very high viscosity and stability, but also not showing properties of sedimentation. Native HP $\beta$-glucan did not dissolve in water, created nonviscous solutions, and moreover, strongly sedimented. Higher viscosity of carboxymethylated $\mathrm{CMG} \beta$-glucan than native $\mathrm{HP} \beta$-glucan, despite comparable particle size, might be explained by the fact that carboxymethylated CMG $\beta$-glucan might be characterised by higher particle mass resulting from additional methyl groups contained in their structure, which in turn enabled ist stronger hydration and viscosity increase.

Many biological experiments showed that the change of physicochemical parameters of $\beta$ glucans as a result of chemical or enzymatic modification might lead to the change of their pro-health influence, changes in sensoric quality [50,51], therefore, it is extremely important to conduct research in case of each newly obtained preparation.

During the evaluation of bioactive substance properties very often the evaluation of antioxidant properties is conducted, which are also checked for native $\beta$-glucan HP and $\beta$ glucan BG-CMG modified through carboxymethylation. The preparations of these $\beta$-glucans were characterised by varied antioxidant activity expressed as TEAC (the number of Trolox milimols for each $1 \mathrm{~g}$ of preparation) - Fig. 9.

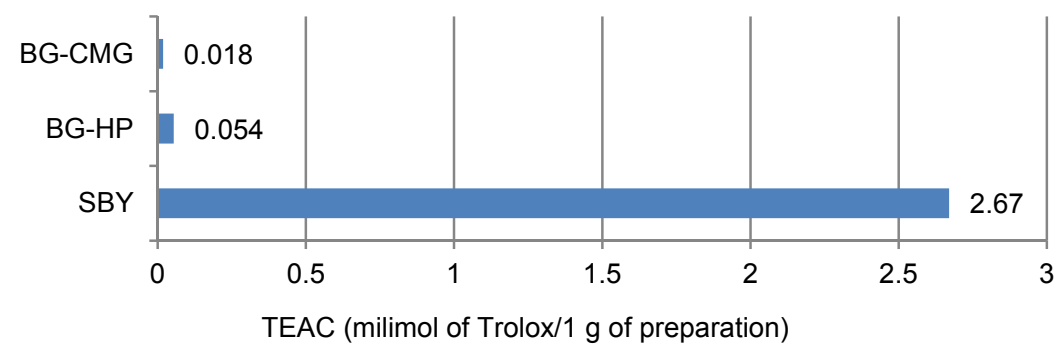

Figure 9. The antioxidant activity of $\beta$-glucan preparations in comparison with spent brewer's yeast. 
The preparation of spent brewer's yeast showed over 50-100 times higher antioxidant activity than $\beta$-glucan BG-HP isolated from them and $\beta$-glucan BG-CMG subject to chemical modification. Such high antioxidant activity of spent dried yeast preparation might result from squalene contained in the preparation, whose presence was confirmed in parallel research at the rate of $125 \mathrm{mg}$ per $100 \mathrm{~g}$ of powder.

\subsection{Blood lipid metabolism}

In numerous research conducted on animals and in clinical research on people, hypocholesterolemic influence of $\beta$-glucans of cereal origin containing $(1 \rightarrow 3) /(1 \rightarrow 4)-\beta$ bindings has been proven. This influence has been confirmed in case of $\beta$-glucans isolated from fungi, containing $(1 \rightarrow 3) /(1 \rightarrow 6)-\beta$ bindings, however, it has been weaker in comparison with cereal $\beta$-glucans. However, there is no literature data on the influence of $\beta$-glucans from spent brewer's yeast on the lipid metabolism of both experimental animals and people [52, 53].

During biological experiment, animals given diets supplemented with $\beta$-glucans HP and CMG and dried spent brewer's yeast grew at a comparable pace. Body mass of animals after the experiment ranged from 390.8 to $412.3 \mathrm{~g}$, and daily growth ranged from 6.5 to $7.2 \mathrm{~g}$. Slight differences between particular groups were not statistically significant. In the groups of animals receiving $\beta$-glucans or spent brewer's yeast, feed efficiency ratio (FER) did not differ significantly and ranged from 0.36 to 0.38 (tab. 4).

\begin{tabular}{|c|c|c|c|}
\hline \multicolumn{2}{|c|}{ Group - experimental factor } & $\begin{array}{c}\text { Diet intake } \\
\text { [g/day }]\end{array}$ & Feed efficiency ratio FER ${ }^{4 /}$ \\
\hline \multicolumn{2}{|r|}{ CONTROL } & $18.1^{\mathrm{a}} \pm 0.4$ & $0.38^{\mathrm{a}} \pm 0.03$ \\
\hline \multirow{4}{*}{ 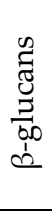 } & BG-CMG10 & $18.0^{\mathrm{a}} \pm 04$ & $0.38^{a} \pm 0.03$ \\
\hline & BG-CMG100 & $17.7^{\mathrm{a}} \pm 0.5$ & $0.36^{\mathrm{a}} \pm 0.03$ \\
\hline & BG-HP10 & $17.7^{\mathrm{a}} \pm 0.7$ & $0.37^{\mathrm{a}} \pm 0.04$ \\
\hline & BG-HP100 & $17.9^{a} \pm 0.4$ & $0.38^{\mathrm{a}} \pm 0.02$ \\
\hline \multicolumn{2}{|c|}{ SBY - spent brewer's yeast } & $17.9^{a} \pm 0.9$ & $0.38^{\mathrm{a}} \pm 0.03$ \\
\hline & $\operatorname{SEM}^{2 /}\left(p^{3 /}\right)$ & $0.067(0.710)$ & $0.004(0.874)$ \\
\hline
\end{tabular}

Table 4. The comparison of intake and nutritious efficiency of diets supplemented with $\beta$-glucan preparations and spent brewer's yeast ${ }^{1 /}(n=63)$.

${ }^{1 /}$ mean values \pm standard deviation for $\mathrm{n}=7$ or $8,{ }^{2 /}$ SEM - standard error mean; ${ }^{3 /}$ ANOVA, $\mathrm{p}<0.05,4 /$ Feed efficiency ratio: body mass growth $(\mathrm{g} /$ day $) \times$ diet intake $^{-1}(\mathrm{~g} / \text { day })^{-1}$, identical letter signs in columns equal the lack of a significant difference between compared mean values

Table 5 and Fig. 10-11 show the results determing the influence of $\beta$-glucans and dried spent brewer's yeast on total cholesterol concentrationm HDL and LDL fraction cholesterol and triacylglycerols in rat blood plasma.

Total cholesterol concentration in the blood of rats in control group, given a model atherogenic diet (1\% cholesterol, $20 \%$ fat) amounted to $3.79 \mathrm{mmol} / \mathrm{l}$ and was significantly 
higher than in all experimental groups. A significantly higher $(\mathrm{p}=0.043)$ concentration of LDL fractions $(1.8 \mathrm{mmol} / \mathrm{l})$ was also observed in the control group. Total cholesterol concentration in the blood of rats given $\beta$-glucans preparations from spent brewer's yeast in the daily amount equalling $100 \mathrm{mg} / \mathrm{kg}$ of bady mass or preparation of spent brewer's yeast ranged from 2.82 to $2.97 \mathrm{mmol} / \mathrm{l}$.The differences between these three groups were, however, insignificant statistically. The concentration of LDL-cholesterol fraction ranged in these groups respectively from 1.09 to $1.11 \mathrm{mmol} / \mathrm{l}$ (tab. 5).

\begin{tabular}{|c|c|c|c|c|c|}
\hline \multirow{2}{*}{\multicolumn{2}{|c|}{$\begin{array}{l}\text { Group - } \\
\text { experimental factor }\end{array}$}} & \multirow{3}{*}{$\begin{array}{c}\text { Total cholesterol } \\
{[\mathrm{mmol} / \mathrm{l}]}\end{array}$} & \multicolumn{3}{|c|}{ Cholesterol fractions } \\
\hline & & & \multirow{2}{*}{$\begin{array}{c}\text { HDL [mmol/l] } \\
1.58^{\mathrm{a}} \pm 0.15\end{array}$} & \multirow{2}{*}{$\begin{array}{c}\text { LDL [mmol/l] } \\
1.80^{\mathrm{a}} \pm 0.12\end{array}$} & \multirow{2}{*}{$\begin{array}{c}\begin{array}{c}\text { VLDL } \\
{[\mathrm{mmol} / \mathrm{l}]}\end{array} \\
0.41^{\mathrm{a}} \pm 0.03\end{array}$} \\
\hline & Control & & & & \\
\hline \multirow{4}{*}{ 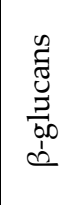 } & BG-CMG10 & $3.23^{b c} \pm 0.23$ & $1.52^{\mathrm{ab}} \pm 0.14$ & $1.35^{b c} \pm 0.14$ & $0.26^{\mathrm{bc}} \pm 0.04$ \\
\hline & BG-CMG 100 & $2.95^{\mathrm{bc}} \pm 0.17$ & $1.51^{\mathrm{ab}} \pm 0.12$ & $1.11^{\mathrm{de}} \pm 0.15$ & $0.33^{\mathrm{bc}} \pm 0.03$ \\
\hline & $\mathrm{BG}-\mathrm{HP}_{10}$ & $3.20^{\mathrm{b}} \pm 0.38$ & $1.56^{\mathrm{ab}} \pm 0.15$ & $1.31^{b c} \pm 0.23$ & $0.31^{\mathrm{bc}} \pm 0.05$ \\
\hline & BG-HP100 & $2.82^{b c} \pm 0.38$ & $1.38^{\mathrm{ab}} \pm 0.19$ & $1.10^{\mathrm{e}} \pm 0.19$ & $0.30^{\mathrm{ab}} \pm 0.16$ \\
\hline & SBY & $2.97^{b c} \pm 0.36$ & $1.39^{\mathrm{b}} \pm 0.13$ & $1.29^{\mathrm{bce}} \pm 0.26$ & $0.30^{\mathrm{bc}} \pm 0.04$ \\
\hline & SEM & $p=0.0065$ & $p=0.415$ & $p=0.043$ & $p=0.0295$ \\
\hline
\end{tabular}

Table 5. Selected lipid parameters of peripheral blood in experimental animals given atherogenic diets, supplemented with $\beta$-glucan preparations and spent brewer's yeast preparation ${ }^{1 /}(n=63)$.

${ }^{1 /}$ mean values \pm standard deviation for $\mathrm{n}=7$ or 8 ; ${ }^{2 /} \mathrm{SEM}-$ standard error mean; ${ }^{3 /}$ ANOVA, $\mathrm{p}<0.05$; identical letter signs in columns equal the lack of significant difference between compared mean values

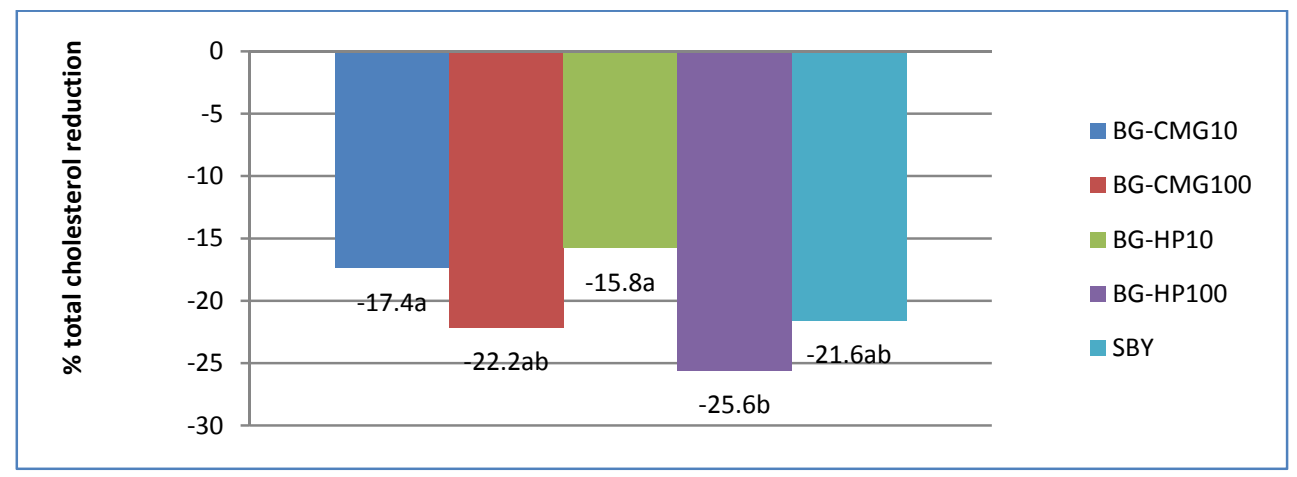

Figure 10. The degree of total cholesterol reduction in peripheral blood of experimental animals on atherogenic diets caused by diet supplementation with $\beta$-glucan preparations and spent brewer's yeast ( $*$ identical letters indicate no significant difference).

It was concluded that diet supplementation with spent brewer's yeast preparation, contributed to achieving lower concentration of total cholesterol of $21.6 \%$. In groups of animals given diets containing $\beta$-glucans in a daily dosage of 10 and $100 \mathrm{mg} / \mathrm{kg}$ of body mass, the concentration of total cholesterol in blood was lower than in control group of 
$22.2 \%$ (in the group with $\beta$-glucan BG-CMG100) and of $25.6 \%$ (in the group with $\beta$-glucan BG-HP100) - Fig. 10. In these groups, LDL-cholesterol fraction was respectively lower of 38.3 to $39.1 \%$ in comparison with control group (Fig. 11).

The type of $\beta$-glucans from spent brewer's yeast (BG-CMG and BG-HP) did not influence significantly the level of total cholesterol in blood $(p=0.638)$, whereas their dosage $(p=$ $0.002)$ had a significant influence. In rats from control group on a model athrogenic diet $(1 \%$ cholesterol, $20 \%$ fat), cholesterol of HDL fraction amounted to $41.7 \%$ of total cholesterol, and LDL fraction cholesterol $-47.5 \%$. The use of examined preparations in diet supplementation caused changes in the configuration of these fractions leading to lowering the LDL fraction participation and increasing percentage participation of HDL fraction cholesterol. Changes of these fractions in total cholesterol (LDL-cholesterol fraction below $40 \%$ of total cholesterol), were particularly visible in groups of rats given CMG and HP $\beta$-glucan preparations from spent brewer's yeast in the amount equalling $100 \mathrm{mg} / \mathrm{kg}$ of body mass daily.

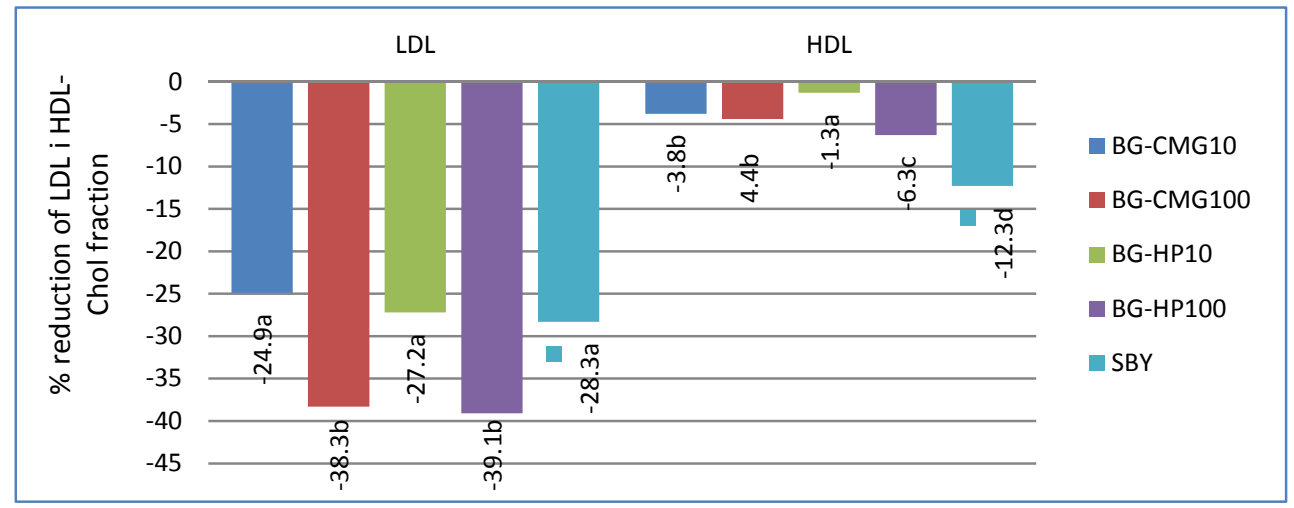

Figure 11. Reduction ratio of LDL and HDL-cholesterol fractions and triacylglycerols in peripheral blood of experimental animals on atherogenic diets caused by diet supplementation with $\beta$-glucan preparations and dried spent brewer's yeast $(* /$ identical letters indicate no significant difference).

Table 6 presents the ratios of atherogenic factors of examined preparations. The ratio of HDL fraction to Chol-C and HDL to LDL fractions, after the experiment completion was in each case significantly higher in comparison with control group, which suggests that each of the examined preparations, regardless of the type and dosage, significantly improves the lipid metabolism of animals given atherogenic diet.

In groups with beta glucan participation, the concentration of triacylglycerols ranged from 0.67 to $0.76 \mathrm{mmol} / \mathrm{l}$ plasma, i.e. was lower in the control group from 14.8 to $25.6 \%$ (tab. 7 , Fig. $10)$.

Dried spent brewer's yeast given to animals in a daily dosage of $100 \mathrm{mg} / \mathrm{kg}$ of body mass contributed to lower the concentration of TG in blood in relation to control group of $27.2 \%$ $(p=0,008)-$ tab. 7, Fig. 12 . 


\begin{tabular}{|c|c|c|c|}
\hline \multirow{2}{*}{\multicolumn{2}{|c|}{ Group - experimental factor }} & \multicolumn{2}{|c|}{ Atherogenic factors } \\
\hline & & HDL/Chol-C & HDL/LDL \\
\hline \multicolumn{2}{|r|}{ CONTROL } & $0.42^{\mathrm{a}} \pm 0.03$ & $0.88^{\mathrm{a}} \pm 0.12$ \\
\hline \multirow{4}{*}{ 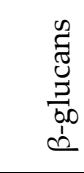 } & BG-CMG10 & $0.49^{\mathrm{bc}} \pm 0.03$ & $1.16 \pm 0.15^{\mathrm{b}}$ \\
\hline & BG-CMG100 & $0.52^{\mathrm{cd}} \pm 0.04$ & $1.39^{c} \pm 0.29$ \\
\hline & BG-HP10 & $0.49^{\mathrm{bc}} \pm 0.02$ & $1.23^{b c} \pm 0.12$ \\
\hline & BG-HP100 & $0.52^{\mathrm{d}} \pm 0.03$ & $1.36^{c} \pm 0.15$ \\
\hline \multicolumn{2}{|r|}{ SBY } & $0.47^{\mathrm{b}} \pm 0.03$ & $1.09^{b} \pm 0.15$ \\
\hline \multicolumn{2}{|r|}{$S E M^{2 /}\left(p^{3 /}\right)$} & $0.006(0.0001)$ & $0.035(0.0001)$ \\
\hline
\end{tabular}

Table 6. The comparison of atherogenic factors characteristic of blood of experimental animals given atherogenic diets with $\beta$-glucan additive and spent brewer's yeast ${ }^{1 /}$.

1/ mean values \pm standard deviation for $\mathrm{n}=7$ or $8 ;{ }^{2 /}$ SEM - standard error mean; ${ }^{3 /}$ ANOVA, $\mathrm{p}<0.05$; identical letter signs in columns equal the lack of significant difference between compared mean values

\begin{tabular}{|c|c|c|}
\hline \multicolumn{2}{|c|}{ Group - experimental factor } & TG - triacylglycerols [mmol/l] \\
\hline \multicolumn{2}{|r|}{ CONTROL } & $0.90^{\mathrm{a}} \pm 0.07$ \\
\hline \multirow{4}{*}{ 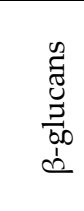 } & $\beta$-glucan BG-CMG10 & $0.72^{\mathrm{b}} \pm 0.06$ \\
\hline & $\beta$-glucan BG-CMG100 & $0.67^{\mathrm{b}} \pm 0.04$ \\
\hline & $\beta$-glucan BG-HP10 & $0.74^{\mathrm{b}} \pm 0.02$ \\
\hline & $\beta$-glucan BG-HP100 & $0.76^{\mathrm{b}} \pm 0.04$ \\
\hline \multicolumn{2}{|r|}{ SBY - spent brewer's yeast } & $0.66^{\mathrm{b}} \pm 0.09$ \\
\hline \multicolumn{2}{|r|}{$\operatorname{SEM}^{2}\left(p^{3}\right)$} & $0.019(0.008)$ \\
\hline
\end{tabular}

Table 7. Selected lipid parameters of peripheral blood of test animals on atherogenic diets, supplemented with $\beta$-glucans and the preparation of dried brewer's yeast ${ }^{1 /}$.

1/ mean values \pm standard deviation for $\mathrm{n}=7$ or $8{ }^{2 /}$ SEM - standard error mean; ${ }^{3 /}$ ANOVA, $\mathrm{p}<0.05$; identical letter signs in columns equal the lack of a significant difference between compared mean values

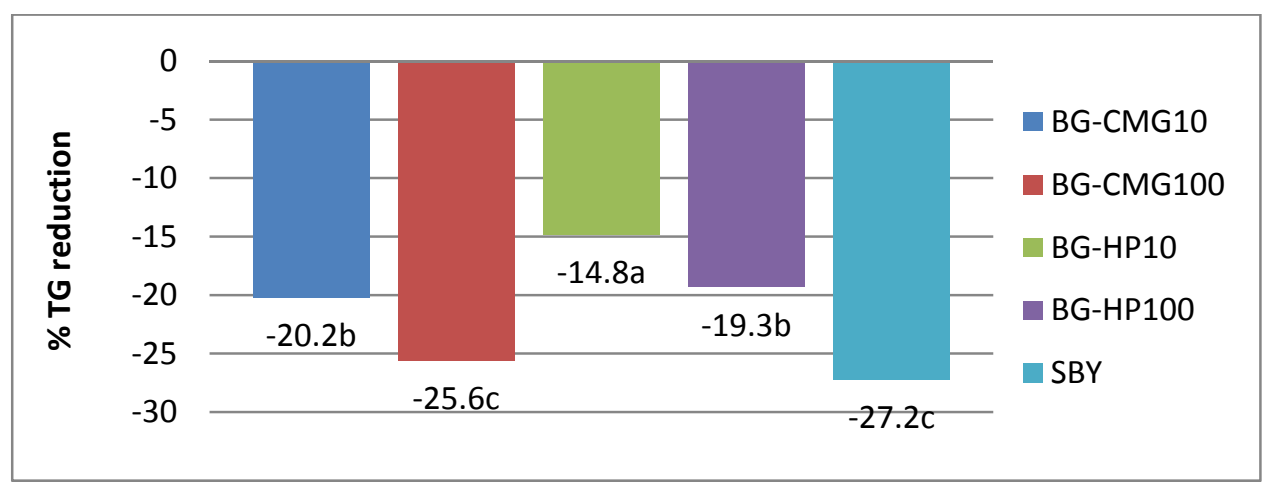

Figure 12. The percentage of lowered (with regard to the control group) the concentration of triacylglycerols (TG) in blood plasma in rats on atherogenic diets supplemented with $\beta$-glucans and dried spent brewer's yeast $(* /$ identical letters indicate no significant difference). 
Two-factor analysis showed the lack of significant influence of the type of $\beta$-glucan (soluble and insoluble) $(p=0.091)$. Also the dosage of these beta glucans did not influence the reduction ratio of $\mathrm{TG}$ in rat blood $(\mathrm{p}=0.786)$.

Table 8 compiles the total content of lipids and cholesterol in liver of rats on atherogenic diets supplemented with $\beta$-glucans and dried spent brewer's yeast. The content of lipids was presented both in the equivalent of the so-called wet tissue and dry mass, whereas cholesterol content was presented in the equivalent of wet tissue and in reference to total lipid content.

\begin{tabular}{|c|c|c|c|c|c|}
\hline \multirow{2}{*}{\multicolumn{2}{|c|}{$\begin{array}{l}\text { Group - experimental } \\
\text { factor }\end{array}$}} & \multicolumn{2}{|c|}{ Lipids } & \multicolumn{2}{|c|}{ Total cholesterol } \\
\hline & & $\begin{array}{l}\mathrm{g} / 100 \mathrm{~g} \text { of wet } \\
\text { tissue }\end{array}$ & $\begin{array}{l}\mathrm{g} / 100 \mathrm{~g} \text { s.m. of } \\
\text { the liver }\end{array}$ & $\begin{array}{l}\mathrm{mg} / 1 \mathrm{~g} \text { of wet } \\
\text { tissue }\end{array}$ & $\mathrm{mg} / \mathrm{g}$ of lipids \\
\hline \multicolumn{2}{|r|}{ Control } & $20.9^{\mathrm{a}} \pm 2.8$ & $47.3^{\mathrm{bc}} \pm 1.3$ & $82.5^{\mathrm{a}} \pm 7.5$ & $432.1^{\mathrm{ab}} \pm 23.7$ \\
\hline \multirow{4}{*}{$\begin{array}{l}0 \\
\tilde{Z} \\
\tilde{E} \\
0 \\
b \\
b\end{array}$} & BG-CMG10 & $19.5^{a} \pm 3.3$ & $42.0^{\mathrm{ab}} \pm 2.7$ & $69.9^{b} \pm 6.0$ & $352.1^{c} \pm 42.6$ \\
\hline & BG-CMG100 & $18.6^{\mathrm{a}} \pm 3.5$ & $39.6^{\mathrm{a}} \pm 4.1$ & $67.5^{\mathrm{bc}} \pm 6.5$ & $340.9^{c} \pm 26.4$ \\
\hline & BG-HP10 & $18.4^{\mathrm{a}} \pm 1.9$ & $42.5^{\mathrm{ab}} \pm 3.9$ & $66.0^{\mathrm{bc}} \pm 1.1$ & $361.4^{c} \pm 28.1$ \\
\hline & BG-HP100 & $18.7^{\mathrm{a}} \pm 34$ & $39.1^{\mathrm{a}} \pm 3.7$ & $65.1^{\mathrm{bc}} \pm 5.4$ & $348.3^{c} \pm 38.8$ \\
\hline & SBY & $19.1^{\mathrm{a}} \pm 2.7$ & $43.4^{\mathrm{ab}} \pm 4.4$ & $65.1^{\mathrm{bc}} \pm 5.0$ & $369.1^{b c} \pm 30.1$ \\
\hline & $\operatorname{SEM}^{2 /}\left(p^{3}\right)$ & $0.110(0.62)$ & $0.513(0.007)$ & $14.4(0.05)$ & $8.16(0.001)$ \\
\hline
\end{tabular}

Table 8. The content of lipids and cholesterol in the liver of rats on atherogenic diets supplemented with $\beta$-glucans and dried spent brewer's yeast.

${ }^{1 /}$ mean values \pm standard deviation for $\mathrm{n}=5$ or 6 ; $2 /$ SEM - standard error mean; ${ }^{3 /}$ ANOVA, $\mathrm{p}<0.05$, identical letter signs in columns equal the lack of a significant difference between compared mean values

Total lipid content in fresh liver mass of rats did not differ significantly $(p=0.110)$ in all groups and ranged from 18.4 to $20.9 \mathrm{~g} / 100 \mathrm{~g}$ of wet tissue. Statistical analysis showed that the type of tested $\beta$-glucans ( $\mathrm{p}=0.287$ ) did not influence the concentration of lipids in the liver, whereas significantly better effects were observed when a higher dosage $(p=0.003)$ was used.

In comparison with cholesterol level, it has been stated that neither the type $(p=0,444)$ nor the amount of $\beta$-glucans $(p=0.720)$ in the diet, significantly influence the cholesterol concentration in the liver.

Table 9 presents the percentage participation of saturated fatty acids (SFA), monounsaturated fatty acids (MUFA) and polyunsaturated fatty acids (PUFA) in total lipid pool in livers. The concentration of these groups of fatty acids was not influenced by the used $\beta$-glucans, but by their dosage $(\mathrm{p}=0.018)$.

The type of $\beta$-glucan from spent brewer's yeast did not significantly influence the ratio of blood lipid parameters metabolism in rats on atherogenic diet containing $1 \%$ of cholesterol. The concentration of HDL-cholesterol fraction and triacylglycerols in rat blood in this case depended neither on the type of $\beta$-glucan nor its dosage. 
Literature data shows that hypolipemic activity of cereal $\beta$-glucans depends on the particle size and therefore, particle mass [54]. Using beta glucans of higher viscosity and higher particle mass in diet supplementation gives a better hypocholesterolemic effect [55]. Particle mass is a significant factor influencing hypocholesterolemic effect of $\beta$-glucans, but also it is essential to pay attention to the method of its designation [56]. Due to the variety of methods used by different researchers, it is difficult to compare experiment results presented by various authors. Hypocholesterolemic effect in people, resulting from cereal $\beta$ glucan intake also depends on the dosage, diet supplementation period and even the age of tested people. $\beta$-glucan intake in the dosage of $3 \mathrm{~g}$ daily for 4 weeks, reduced the cholesterol concentration in the blood of children and teenagers with mild hypercholesterolemia of about $6-7 \%$ [57]. After 40 days of consuming diet containing from 1 to $5 \%$ of $\beta$-glucan from barley, total cholesterol concentration was reduced of 39\%, LDL cholesterol fraction of $61 \%$ and triacylglycerols of $21 \%$.

\begin{tabular}{|c|c|c|c|c|}
\hline \multirow{2}{*}{\multicolumn{2}{|c|}{$\begin{array}{l}\text { Group - } \\
\text { experimental factor }\end{array}$}} & \multicolumn{3}{|c|}{$\%$ fatty acids in total pool of lipids } \\
\hline & & Saturated SFA & $\begin{array}{c}\text { Monounsaturated } \\
\text { MUFA }\end{array}$ & $\begin{array}{c}\text { Polyunsaturated } \\
\text { PUFA }\end{array}$ \\
\hline \multicolumn{2}{|r|}{ Control } & $20.8^{a} \pm 2.9$ & $26.7^{\mathrm{a}} \pm 2.2$ & $48.6^{\mathrm{ab}} \pm 3.7$ \\
\hline \multirow{4}{*}{ 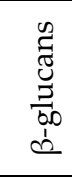 } & BG-CMG10 & $19.1^{\mathrm{abc}} \pm 1.9$ & $26.7^{a} \pm 0.6$ & $44.8^{\mathrm{bc}} \pm 2.4$ \\
\hline & BG-CMG100 & $15.4^{\mathrm{c}} \pm 1.0$ & $31.7^{\mathrm{b}} \pm 1.4$ & $51.4^{a} \pm 0.7$ \\
\hline & BG-HP10 & $19.2^{\mathrm{ab}} \pm 4.2$ & $28.7^{\mathrm{ab}} \pm 4.0$ & $44.6^{c} \pm 4.1$ \\
\hline & BG-HP100 & $15.9^{\mathrm{bc}} \pm 0.6$ & $29.6^{\mathrm{ab}} \pm 2.5$ & $45.1^{\mathrm{bc}} \pm 0.1$ \\
\hline \multicolumn{2}{|r|}{ SBY } & $15.9^{\mathrm{bc}} \pm 0.4$ & $27.0^{\mathrm{a}} \pm 1.2$ & $50.5^{a} \pm 0.7$ \\
\hline \multicolumn{2}{|r|}{$S E M^{2 /}\left(p^{3 /}\right)$} & $0.578(0.023)$ & $0.856(0.0001)$ & $0.841(0.0001)$ \\
\hline
\end{tabular}

Table 9. The percentage participation of fatty acids in total lipid pool of livers in experimental rats given $\beta$-glucan preparations and spent brewer's yeast.

${ }^{1 /}$ mean values \pm standard deviation for $\mathrm{n}=5$ or $6 ;{ }^{2 /}$ SEM - standard error mean; ${ }^{3 /}$ ANOVA, $\mathrm{p}<0.05$; identical letter signs in columns equal the lack of a significant difference between compared mean values

Significant results were obtained also as a result of $5 \%$ supplementation of rats' diet with $\beta$ glucan from oyster mushroom (Ostreatus Pleurotus). Such a level in the low- and highcholesterol diet lowered the concentration of cholesterol, including LDL and VLDL cholesterol fractions, in both cases of about $30 \%$ in blood plasma and of about $50 \%$ in the liver, which was simultaneously connected with lowering of HMG - CoA reductase activity [58].

This work has not confirmed significant differencies between hypocholesterolemic effect of carboxymethylated $\beta$-glucan (soluble, of higher particle mass) and native $\beta$-glucan (insoluble).

The influence of $\beta$-glucans on lipid metabolism depends to a large extent on the size of their particles. The carboxymethylated $\beta$-glucan isolated in the laboratory from baker's yeast Saccharomyces cerevisiae, had a very low hipocholesterolemic activity despite its good solubility and high viiscosity. It has been explained by authors by the fact that apart from 
the process of carboxymethylation, $\beta$-glucan underwent additional depolymerisation of particles through the use of ultrasounds. It led to a significant lowering of its particle mass, and therefore, the direction of its pro-health influence was changed.

In the research on humans using cereal $\beta$-glucans in the diet, an atherogenic factor was expressed as the ratio of HDL cholesterol to LDL cholesterol, in almost every case was increased in comparison with control group. A similar effect was obtained in the research described in this work. Diet supplementation with $\beta$-glucan isolated from spent brewer's yeast and preparation of dried yeast influenced the value of HDL/Chol-total ratio and HDL/LDL ratio. In each case of diet supplementation, these ratios were significantly more advantageous than in control group, which used only atherogenic diet [59].

Dried spent brewer's yeast given to animals in the diet in the amount of $0.5 \%$ diet, were as efficient as $\beta$-glucan preparations prepared from them and helped to lower the concentration in blood of: total cholesterol of $21.6 \%$, LDL fraction - of $28.2 \%$ and triacylogliceroles of $27.2 \%$ in relation to control group.

Available literature data concerning the influence of diet supplementation with yeast preparations as the source of dietary fibre concerns in most cases other types or species of yeast. In the research on obese men with hypercholesterolemia have shown that intake of 15 $\mathrm{g}$ of fibre from spent brewer's yeast (containing $\beta$-glucan) advantageously lowered the concentration of total cholesterol in blood, increasing the concentration of HDL fraction cholesterol. Simultaneously, the changes in the concentration of triacylogliceroles in blood were not observed. Authors, however, did not give the exact consitution of yeast fibre, which made it difficult to compare these results with the results obtained in this work [60].

Lowering of the concentration of total cholesterol in blood of experimental animals, as a result of diet supplementation with yeast, might be the result of not only $\beta$-glucan contained in them, but also the presence of squalens [61]. The ability of correcting blood lipid metabolism as a result of diet supplementation with yeast might result from the prebiotic properties of both the whole dried yeast cells and beta glucans contained in them, thanks to which the composition of natural bacterial flora can be additionally corrected [62].

As the research results show, the degree of liver fatness was significantly influenced by the dosage of beta glucans from spent brewer's yeast, whereas the solubility did not matter statistically. Both examined $\beta$-glucan preparations were given in daily dosage of $100 \mathrm{mg} / \mathrm{kg}$ of body mass, efficiently protected the liver against excessive fat layering.

The type of $\beta$-glucans from spent brewer's yeast and their amount used in the diet did not, however, influence the cholesterol concentration in the livers. In comparison with the control group, the participation of cholesterol in liver lipids was in each case significantly lower. Two-factor analysis of variance showed that the higher dosage of $\beta$-glucans in the diet, i.e. $100 \mathrm{mg} / \mathrm{kg}$ of body mass daily, contributed to higher concentration of polyunsaturated fatty acids (PUFA) in livers and simultaneously lower concentration of saturated fatty acids (SFA). The dosage of $\beta$-glucans did not significanlty influence the concentration of monounsaturated fatty acids (MUFA). The concentration of all these 
groups of fatty acids was not influenced by the type of used $\beta$-glucans. Dried spent brewer's yeast, like $\beta$-glucans, also contributed to obtaining lower concentration of cholesterol in calculation for the wet tissue of the liver.

Beta glucans, regardless of origin, serve as dietary fibre in the body of mammals, therefore, their hipocholesterolemic effect might be associated with the mechanism recognised for dietary fibre. The influence of soluble fractions of dietary fibre on the cholesterol concentration in the body is known, by binding bile acids in the intestine and consequently increases the amount of bile acids excreted in the feces. It results in decreasing the pool of bile salt able to take part in the synthesis of cholesterol in liver and disregulation of micellas in intestines, which hampers lipid absorption. Cholesterol is used in the synthesis of bile acids instead of lipoproteid synthesis, therefore, speeding its circulation, and its concentration in plasma lowers $[63,64]$.

Hipocholesterolemic effect of tested $\beta$-glucans might be also compared with the activity of known prebiotic (inulin) and oat fibre. Inulin while undergoing fermentation in large intestine influences the proportions of produced SCFA [65], decreasing the amount of produced octan, and increasing the level of propionic and butyric acid. It is especially advantageous, as octan acts as a simulator and propionian as inhibitor of cholesterol synthesis [66]. Research in vitro showed that propionic acid hampers cholesterol and fatty acid synthesis in the liver. It seems that the combination of increased excretion of bile acid with faeces and slight lowering of cholesterol synthesis in liver aims to lower total cholesterol concentration and LDL fraction in blood [67].

Supplementation of rat diets with $\beta$-glucan preparations from spent brewer's yeast examined in this work and the preparation of dried brewer's yeast contributes to advantegous lowering of cholesterol concentration in blood, at simultaneous achieving a more advantegous in relations to control group content of bowel microflora, connected particularly with increased numer of Bifidobacterium bacteria of lactid acid, which was shown in parallelly conducted research.

It is quite difficult to explain the estimated mechanism of lowering cholesterol concentration under the influence of prebiotics. However, increased excretion of cholesterol with faeces through hampering the creation of easily digested fatty micellas has been suggested. In rats, increased excretion of cholesterol in faeces has been confirmed, and similar research presents this mechanism also in people. It is possible that some bacteria of lactid acid can assimilate cholesterol directly. There is proof that fructooligosaccharides (FOS) lower the synthesis of triacylglycerols in liver, however, so far the mechanism has not been identified.

Similar significance to probiotics is also attributed to prebiotics. Prebiotics arouse even greater interest due to practical means - they are characterised by greater durability than probiotics, their activity is not conditioned by micorbe viability after intake and they might be added to many food products as one of the ingredients. There is little research available concerning the research on people, therefore, most conclusions have been drawn based on the research on animals. In rats, for example, after a 5-week inulin administration a 
significant lowering of triacyloglicerole concentration was observed. In people, however, oligofructose administration for 4 weeks did not lead to lowering triacylogliceroles and cholesterol [68]. Especially strong influence of prebiotics on lowering VLDL fraction is suggested [69].

\section{Conclusions}

No significant differences have been observed in hypocholesterolemic effect of soluble $\beta$ glucan - $(\mathrm{CMG})$ and insoluble native $\beta$-glucan $(\mathrm{HP})$. The results showed that after hydration, carboxymethylated $\beta$-glucan CMG was characterised by higher viscosity and mean particle size amounting to about $90 \mu \mathrm{m}$, whereas particles of insoluble HP $\beta$-glucan, established nonviscous solutions of particle size amounting to about $50 \mu \mathrm{m}$ and about 320 $\mu \mathrm{m}$. Examined $\beta$-glucans showed an effective hypocholesterolemic effect. It has been proven that they influenced lipid metabolism advantageously, especially in case of LDL fraction cholesterol and triacylglycerols (TG). An advantageous HDL/Chol-total factor and HDL/LDL factor has also been confirmed. Dried spent brewer's yeast were given to animals in a daily dosage of $100 \mathrm{mg} / \mathrm{kg}$ of body mass were as efficient as $\beta$-glucans isolated from them and they lowered the concentration in blood of: total cholesterol of $21.6 \%$, LDL fraction - of $28.2 \%$ and triacylglycerols of $27.2 \%$ in relation to control group. The research also proves that advantageous influence of yeast on lipid metabolism and their level in blood might be linked with prebiotic properties of yeast on lipid metabolism, as in the research simultaneously conducted by the Author, the advantageous composition of intestine microflora was observed (a higher number of lactid acid bacteria of Bifidobacterium type was obtained).

High nucleic acid content in yeast (supplying from $12 \%$ to $25 \%$ of total nitrogen content) [70] limits their use as a traditional ingredient in human nutrition. It has been stated that the excess of nucleic acid in the diet of people and most monogastric animals is toxic and results in excessive accumulation of uric acid in organism, leading to arthritis. Therefore, it is recommended to consume their little portions as diet supplement supplying mainly vitamins from B group.

Numerous research on fish proved that diet supplementation with yeast to a particular level (in the amount providing no more than $50 \%$ of proteins in the diet), does not show disadvantageous health effects, such as abnormal growth, improper nitrogen balance or liver diseases [71]. However, only lower diet intake was observed when spent brewer's yeast constituted more than $25 \%$ of the diet [70]

It seems that diet supplementation with dried spent brewer's yeast S.cerevisiae in the amount of $0.5 \%$ of the diet contributed significantly to correcting possible disorders in lipid metabolism of rats on an atherogenic diet - it enhances lipid changes in organism, enhancing their parameters.

During the research on hypocholesterolemic activity of 81 different yeast strains, showed hypocholesterolemic activity of spent brewer's yeast of male Wistar rats with their 


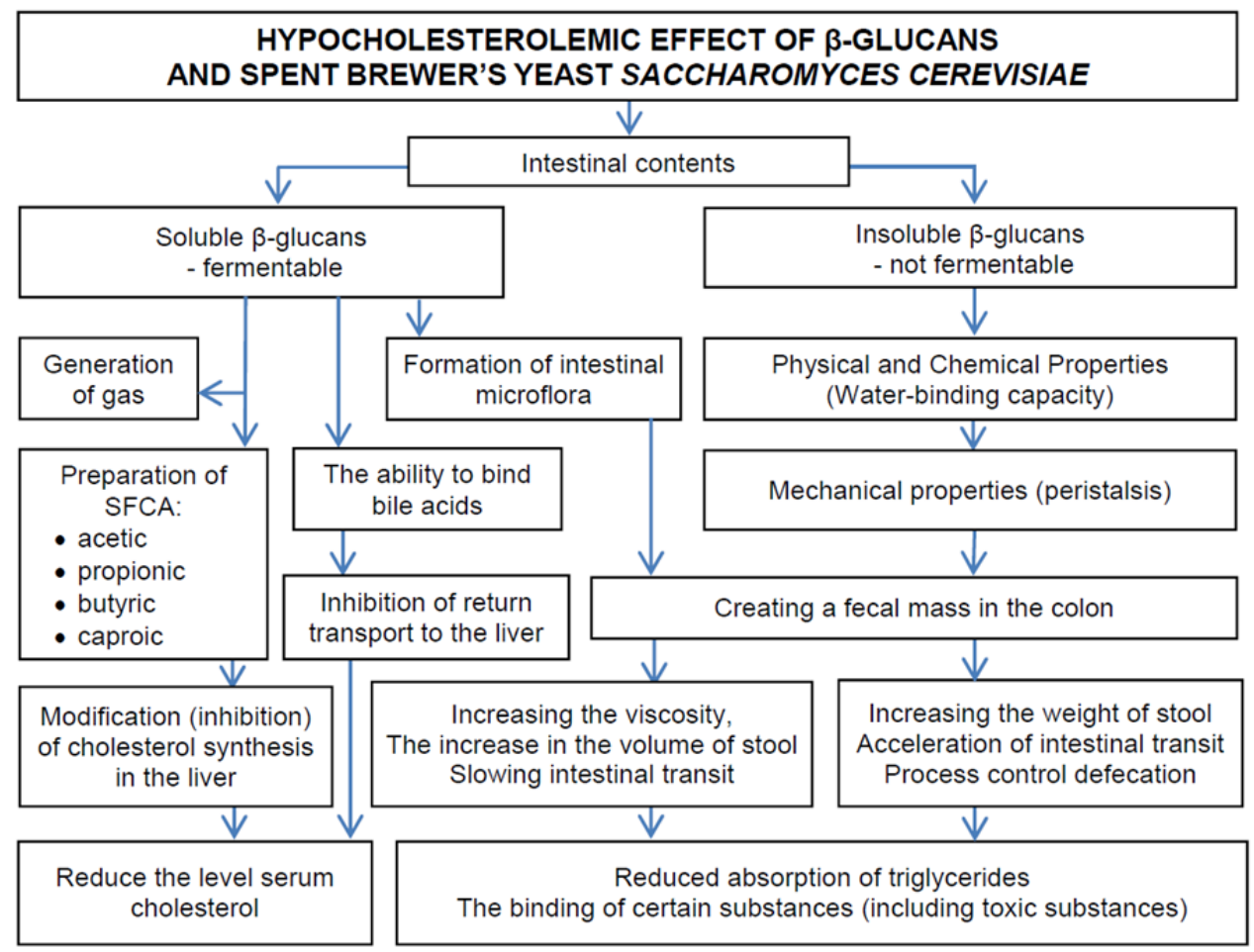

Figure 13. Probable mechanism of hypocholesterolemic effect of beta-glucans and spent brewer's yeast Saccharomyces cerevisiae.

participation of $10 \%$ in the diet [72]. The hypocholesterolemic activities of the yeast varied remarkably between strains. In contrast, brewer's yeast and baker's yeast, which have been predominantly used for food, did not exhibit hypocholesterolemic activity even when administered at concentration of $10 \%$. Whereas, during the research on obese men with hypocholesterolemy it has been shown that the intake of spent brewer's yeast considerably lowers the concentration of total cholesterol, increasing the concentration of advantageous fraction of HDL cholesterol when consumed in the amount supplying $15 \mathrm{~g}$ of fiber daily. Triacylglycerol concentration in blood did not change considerably [60]. The yeast-derived bglucan fiber significantly lowered total cholesterol concentrations and was well tolerated; HDL-cholesterol concentrations rose, but only 4 weeks after the fiber was stopped. Described varied hypocholesterolemic activity of various spent brewer's yeast results among others from the kind of yeast and the amount of their supplementation in the diet. Advantageous lowering of cholesterol concentration in the blood of test animals due to diet supplementation with yeast can be caused by prebiotic properties of yeast, which corrects natural content of bacterial flora [61] or considerably high amount of squalens in yeast lipids [62].

A probable mechanism of HP beta glucan and insoluble, dried brewer's yeast influence presented in the diagram (Fig. 13) is associated with their advantageous influence on testine 
peristlsis and lowering HMG (3-hydroxy-3-methylglutaryl) CoA reductase activity, since also lowering of cholesterol concentration in liver was obtained.

The influence of soluble beta glucan fractions (CMG) on cholesterol concentration in the body was associated with the ability to bind bile acids in a small testine. It might have led to a decrease in bile salt pool able to participate in cholesterol synthesis in liver and disregulation of micellas creation in testine, which hampered lipid absorption. Cholesterol was then used to a larger extent in bile acid synthesis rather than lipoproteid synthesis, therefore, its concentration in blood plasma was decreased. CMG and HP $\beta$-glucans given in a higher dosage (100 mg/kg of body mass daily), protected the liver more efficiently against excessive fat layering. Dried spent brewer's yeast also contributed to obtaining lower cholesterol concentration in liver in comparison with control group.

\section{Requests}

Present interest of consumers to a large extent concerns food that can be used in prevention of many diet-dependent diseases, whereas the interest of food industry is directed at the search for new ingredients of pro-health influence. The knowledge of functional properties of preparations containg $\beta$-glucans might be used to shape proper quality of food products for special purposes.

$\beta$-Glucan is a valuable functional ingredient and various extraction techniques are available for its extraction. Choice of an appropriate extraction technique is important as it may affect the quality, structure, rheological properties, molecular weight, and other functional properties of the extracted $\beta$-glucan. These properties lead to the use of $\beta$-glucan into various food systems and have important implications in human health.

Diet supplementation with $\beta$-glucans from spent brewer's yeast and preparation of dried spent brewer's yeast contributed to advantageous lowering of cholesterol concentration in blood and lowering lipid concentration in liver. The results described above allow for the formulation of the following conclusions:

1. $\beta$-glucan preparations obtained from spent brewer's yeast and dried spent brewer's yeast show efficient biological activity, connected with the improvement of blood lipid profile and liver of experimental animals.

2. Spent brewer's yeast show a similar pro-health influence to $\beta$-glucans isolated from them, therefore, they can be a valuable and much cheaper diet suplement, correcting blood lipid metabolism disturbed by atherogenic diet.

3. $\beta$-glucan preparations from spent brewer's yeast (CMG and HP) given in higher doses (100 mg/kg of body mass daily), efficiently protect liver against excessive fat layering.

Results obtained in the experiment described above with various yeast preparations are valuable, since they point out that $\beta$-glucans obtained from a new source, i.e. spent brewer's yeast have a hypocholesterolemic effect, similarly to other glucans described in literature. Moreover, it has been shown that each of examined $\beta$-glucans isolated from spent brewer's 
yeast was as efficient. Final effect correcting lipid metabolism, particularly various fractions of lipids, was more connected with the dose, rather than physic-chemical properties.

Health advantages contributing to significant cholesterol reduction in blood obtained in experiments on animals, might constitute the basis for assuming that similar influence will be observed in case of a human body. Therefore, it would be recommended to supplement human diet with $\beta$-glucans, particularly for people whose diet is abundant in fat and cholesterol. Spent brewer's yeast constituting a serious problem for brewing plants (waste material), can be used successfully as a valuable source of beta glucans, which can be used as diet supplements or as food additives, e.g. in yoghurts, breakfast desserts or snacks.

Currently conducted research is the continuation of a presented experiment. It shows that atherogenic diet supplementation with beta-glucans or spent brewer's yeast contributed to simultaneous obtaining more advantageous content of testine microflara in relation to control group, connected with the increased number of lactid acid bacteria Bifidobacterium and Lactobacillus and limited growth frequency of disadvantageous yeast fungi Candida albicans. Conducted research on functional properties and biological experiment proves the complexity of $\beta$-glucan and other fibre preparation influence on experimental animals.

\section{Author details}

Bożena Waszkiewicz-Robak

Warsaw University of Life Sciences (WULS-SGGW),

Faculty of Human Nutrition and Consumer Sciences,

Department of Functional Foods and Commodity, Warsaw, Poland

\section{References}

[1] Report of the Joint WHO/FAO export consultation. Geneva, 2002. Diet, nutrition and prevention of chronic disease.

[2] Ahmad A, Anjum FM, Zahoor T, Nawaz H, Dilshad SM.. Beta glucan: a valuable functional ingredient in foods. Crit Rev Food Sci Nutr. 2012;52(3) 201-12.

[3] Tada R, Tanioka A, Iwasawa H, Hatashima K, Shoji Y, Ishibashi K, Adachi Y, Yamazaki M, Tsubaki K, Ohno N. Structural characterisation and biological activities of a unique type beta-D-glucan obtained from Aureobasidium pullulans. Glycoconj J. 2008;25(9) 851-61.

[4] Sandeep Rahar, Gaurav Swami, Navneet Nagpal, Manisha A. Nagpal, Gagan Shah Singh. Preparation, characterization, and biological properties of $\beta$-glucans. J Adv Pharm Technol Res. 2011;2(2) 94-103.

[5] Peumans W.J., Barre A., Derycke V., Rougé P., Zhang W., May G.D., Delcour J.A., Van Leuven F., Van Damme E. J. M. Purification, characterization and structural analysis of an abundant $\beta$-(1,3)-glucanase from banana fruit. Eur. J. Biochem. 2000;267(4) 1188-95.

[6] Zeković D.B., Kwiatkowski S. Natural and Modified $(1 \rightarrow 3)-\beta$-D-Glucans in Health Promotion and Disease Alleviation. Crit. Rev. Biotechnol. 2005;25 205-30. 
[7] Hromadkova Z., Ebringerova A., Sasinkov V., Sandula J., Hrıbalova V., Omelkova J. Influence of the drying method on the physical properties and immunomodulatory activity of the particulate $(1 \rightarrow 3)$-b-D-glucan from Saccharomyces cerevisiae. Carbohyd. Polym. 2003;51(1) 9-15.

[8] Kuniak L., Karácsonyi S., Augusti J., Ginterová A., Széchényl S., Kravarik D., Dubaj J., Varjú J. A new fungal glucan and its preparation. 1993. World Patent number 9312243.

[9] Williams D.L., Browder I., DiLuzio N.R. Soluble phosphorylated glucan: methods and compositions for wound healing. 1990. U.S. Patent number 4975421.

[10] Petrus H.A., Ensley H.E., McNamee R.B., Jones E.L., Browder I.W., Williams D.L. Isolation, physicochemical characterization and preclinical efficacy evaluation of soluble scleroglucan. Am. Society for Pharma. and Experim. 1991;257(1) 500-10.

[11] Ohno N., Uchiyama M., Tsuzuki A., Tokunaka K., Miura N.N., Adachi Y., Aizawa M.W., Tamura H., Tanaka S., Yadomae T. Solubilization of yeast cell-wall $\beta-(1 \rightarrow 3)$-Dglucan by sodium hypochlorite oxidation and dimethyl sulfoxide extraction. Carbohyd. Res. 1999;316(1-4) 161-72.

[12] Takuma Sasaki, Yukio Sugino. Carboxymethylated derivatives of beta-1,3-glucan. 1984 . US Patent number: 4454315.

[13] Šoltés L., Alföldi J., Sandula J. HPLC and C-NMR study of carboxymethyl- $\beta-(1 \rightarrow 6)-D-$ gluco- $\beta$ - $(1 \rightarrow 3)$-D-glucan derived from Saccharomyces cerevisiae. J. Appl. Polym. Sci. 1993;48 1313-19.

[14] Zhang P., hang L., Cheng S. Solution properties of an alpha-(1 $\rightarrow 3)-D$-glucan from Lentinus edodes and its sulfated derivatives. Carbohyd. Res. 2002;337(2) 155-60.

[15] Colleoni-Sirghie M., Kovalenko I.V., Briggs J.L., Fulton B., White P.J. Rheological and molecular properties of water soluble $(1,3) /(1,4)-\beta$-D-glucans from high- $\beta$-glucan and traditional oat lines. Carbohyd. Polym. 2003;52(4) 439-47.

[16] Bednarski W., Reps A. Food Biotechnology (in Polish). Scientific and Technical Publishing House (WNT), Warsaw; 2001.

[17] Onwurah I.N.E., 2001. Crystallinity and polysaccharide chains of $\beta$-glucan in white sorghum, SK5912. Int. J. Biol. Macromol. 29, 281-286.

[18] Charles S., Brennan C.S., Cleary L.J. The potential use of cereal $(1 / 3,1 / 4)-\beta$-D-glucans as functional food ingredients. J. Cereal Sci. 2005;42(1) 1-13.

[19] Smith K.N., Queenan K., Thomas, W., Fulcher, G., Slavin, J. Cholesterol-lowering effect of barley beta-glucan in hypercholesterolemic subjects. FASEB J., 2004;18 A149.

[20] Poyhonen U.L. Control of blood glucose through oat soluble fibre beta-glucan. AgroFood-Industry Hi-Tech. 2004;15 10-1.

[21] FDA. Food labeling: Health claims; soluble dietary fiber from certain foods and coronary heart disease. Interim final rule. Fed Register. 2002;67(191) 61773-83.

[22] Kerckhoffs D.A.J.M., Hornstra G., Mensink R.P. Cholesterol lowering effect of $\beta$-glucan from oat bran in mildly hypercholersterolemic subjects may decrease when $\beta$-glucan is incorporated into bread and cookies. Am. J. Clin. Nutr. 2004;(78) 221-27.

[23] Kofuji K., Aoki A., Tsubaki K., Konishi M., Isobe T., Murata Y. Antioxidant Activity of $\beta$ Glucan. ISRN Pharm., 2012.

[24] Talati R., Baker W.L., Pabilonia M.S., White C.M., Coleman C.I. The Effects of BarleyDerived Soluble Fiber on Serum Lipids. Ann Fam Med. 2009;7(2) 157-63. 
[25] Lull C., Wichers H.J., Savelkoul H.F.J. Antiinflammatory and Immunomodulating Properties of Fungal Metabolitem. Mediat. Inflamm. 2005;(2), 63-80.

[26] Manzi P., Pizzoferrato L. Beta glucans in edible mushrooms. Food Chem., 2000;(68) 31518.

[27] Ishibashi K.I., Miura N.N., Adachi Y., Tamura H., Tanaka S., Ohno N. The solubilization and biological activities of Aspergillus $\beta$-(1/3)-D-glucan. FEMS Immunol. Med. Mic. 2004;(42) 155-66.

[28] Kumar C.G., Joo H.S., Choi J.W., Koo Y.M., Chang C.S. Purification and characterisation of an extracellular polysaccharide from haloalkalophilic Bacillus sp. I-450. Enzyme Microb. Tech. 2004;34(7) 673-81.

[29] Ding X., Hang J., Jiang P., Xu X., Liu Z. Structural features and hypoglycaemic activity of an exopolysaccharide produced by Sorangium cellulosum. Lett. Appl. Microbiol. 2004;38(3) 223-28.

[30] Kony D.B., Damm W., Stoll S., van Gunsteren W.F., Hünenberger P.H. Explicit-Solvent Molecular Dynamics Simulations of the Polysaccharide Schizophyllan in Water. Biophys J. 2007;93(2) 442-55.

[31] Standish L.J., Wenner A.A., Sweet E.S., Bridge C., Nelson A., Martzen M., Novack J., Torkelson C. Trametes versicolor Mushroom Immune Therapy in Breast Cancer. J. Soc. Integr Oncol. 2008;6(3)122-28.

[32] Oba K, Kobayashi M, Matsui T, Kodera Y, Sakamoto J. Individual patient based metaanalysis of lentinan for unresectable/recurrent gastric cancer. Anticancer Res. 2009;29(7) 2739-45.

[33] Schmid J., Müller-Hagen D., Bekel T., Funk L., Stahl U., Sieber V., Meyer V. Transcriptome sequencing and comparative transcriptome analysis of the scleroglucan producer Sclerotium rolfsii. BMC Genomics. 2010;11 329.

[34] Jong Suk Lee, Su-Young Park, Dinesh Thapa, Mi Kyoung Choi, Ill-Min Chung, YoungJoon Park, Chul Soon Yong, Han Gon Choi, Jung-Ae Kim. Grifola frondosa water extract alleviates intestinal inflammation by suppressing TNF- $\alpha$ production and its signaling. Exp Mol Med. 2010;42(2)143-54.

[35] Dai H, Han XQ, Gong FY, Dong H, Tu PF, Gao XM. Structure elucidation and immunological function analysis of a novel $\beta$-glucan from the fruit bodies of Polyporus umbellatus (Pers.) Fries. Glycobiology, 2012. DOI: 10.1093/glycob/cws099.

[36] Kenyon W.J., Esch S.W., Buller C.S. The curdlan-type exopolysaccharide produced by Cellulomonas flavigena KU forms part of an extracellular glycocalyx involved in cellulose degradation. Anton. Leeuw. 2005;87(2) 143-48.

[37] Kanzawa Y., Harada A., Takeuchi M., Yokota A., Harada T. Bacillus curdlanolyticus sp. nov. and Bacillus kobensis sp. nov., which hydrolyze resistant curdlan. Int. J. Syst. Bacteriol. 1995;45(3) 515-21.

[38] Obst M., Sallam A., Luftmann H., Steinbuchel A. Isolation and characterization of grampositive cyanophycin-degrading bacteria-kinetic studies on cyanophycin depolymerase activity in aerobic bacteria. Biomacromolecules. 2004;5(1) 153-61.

[39] Stasinopoulos S.J., Fisher P.R., Stone B.A., Stanisich V.A., 1999. Detection of two loci involved in $(1 \rightarrow 3)$ - $\beta$-glucan (curdlan) biosynthesis by Agrobacterium sp. ATCC31749, and comparative sequence of the putative curdlan synthase gene. Glycobiology, 1999;9(1) 31-41. 
[40] Ross P., Mayer R., Benziman M. Cellulose biosynthesis and function in bacteria. Microbiol. Rev. 1991;55 35-58.

[41] Khalikova E., Susi P., Korpela T. Microbial Dextran-Hydrolyzing Enzymes: Fundamentals and Applications. Microbiol Mol Biol Rev. 2005;69(2) 306-25.

[42] Blättel V., Larisika M., Pfeiffer P., Nowak C., Eich A., Eckelt J., König H. $\beta$-1,3-Glucanase from Delftia tsuruhatensis Strain MV01 and Its Potential Application in Vinification. Appl Environ Microbiol. 2011;77(3) 983-90.

[43] Lesage G., Bussey H. Cell Wall Assembly in Saccharomyces cerevisiae. Microbiol Mol Biol Rev. 2006;70(2) 317-43.

[44] Cross G.G., Jennings H.J., Whitfield D.M., Penney C.L., Zacharie B., Gagnon L. Immunostimulant oxidized $\beta$-glucan conjugates. Int. Immunopharmacol. 2001;1(3) 53950.

[45] Reeves P.G., Nielsen F.H., Fahey G.C. AIN-93 purified diets for laboratory rodents: final report of the American Institute of Nutrition ad hoc writing committee on the reformulation of the AIN-76A rodent diet. J. Nutr. 1993;123 1939-51.

[46] Re R., Pellegrini N., Proteggente A., Pannala A., Yang M., Rice-Evans C. Antioxidant activity applying an improved ABTS radical cation decolorization assay. Free Radical Bio. Med. 1999;26 1231-37.

[47] Folch J., Lees M., Stanley G.H.S. A simple method for the isolation and purification of total lipids from animal tissues. J. Biol. Chem.1957;226(1) 497-09.

[48] Friedewald W.T., Levy R., Fredrickson D.S. Estimation of the concentration of lowdensity lipoprotein cholesterol in plasma, without use of the preparative ultracentrifuge. Clin. Chem. 1972;(18) 499-02.

[49] Wang Q., Wood P.J., Cui W. Microwave assied dissolution of $\beta$-glucan in water implications for the characterisatotion of his polmer. Carbohyd. Polym. 2002;47(1) 35-8.

[50] Hozová B., Kuniak Ł., Kelemenová B. Application of $\beta$-D-Glucans Isolated from Mushrooms Pleurotus ostreatus (Pleuran) and Lentinus edodes (Lentinan) for Increasing the Bioactivity of Yoghurts. Czech. J. Food Sci. 2004;22(6) 204-14.

[51] Volikakis P., Biliaderis C.G., Vamavakas C., Zerfiridis G.K. Effects of a commercial oat$\beta$-glucan concentrate on the chemical, physico-chemical and sensory attributes of a lowfat white-brined cheese produkt. Food Res. Int. 2004;37(1) 83-94.

[52] Othman R.A., Moghadasian M.H., Jones P.J. Cholesterol-lowering effects of oat $\beta$ glucan. Nutr Rev. 2011;69(6) 299-09.

[53] Wolever TM, Gibbs AL, Brand-Miller J, Duncan AM, Hart V, Lamarche B, Tosh SM, Duss R. Bioactive oat $\beta$-glucan reduces LDL cholesterol in Caucasians and nonCaucasians. Nutr J. 2012;25(10) 130.

[54] Brown G.D., Gordon S., 2003. Fungal beta-glucans and mammalian immunity. Immunity. 2003;19(3) 311-15.

[55] Vetvicka V., Yvin J.C. Effects of marine $\beta-1,3$ glucan on immune reactions. Int. Immunopharmacol. 2004;4 721-30.

[56] Biörklund M., van Rees A, Mensink R.P., Onning G. Changes in serum lipids and postprandial glucose and insulin concentrations after consumption of beverages with $\beta$ glucan from oats or barley: a randomised dose-controlled trial. Eur. J. Clin. Nutr. 2005;59(11) 1272-81. 
[57] Maki K.C., Davidson M.H., Ingram K.A., Veith P.E., Bell M., Gugger E. Lipid responses to consumption of a beta-glucan containing ready-to-eat cereal in children and adolescents with mild-to-moderate primary hypercholesterolemia. Nutr. Res. 2003; 23(11) 1527-35.

[58] Bobek P, Hromadova M, Ozdin L. Oyster mushroom (Pleurotus ostreatus) reduces the activity of 3-hydroxy-3-methylglutaryl CoA reductase in rat liver microsomes. Cell. Mol. Life Sci. 1995;51(6) 589-91.

[59] Clevidence B.A., Judo J.T., Schatzkin A., Muesing R.A., Campbell W.S., Brown C.C., Taylor P.R. Plasma lipid and lipoproteid concentration of men consuming a law FAT, high fiber diet. Am. J. Clin. Nutr. 1992;(55) 689-94.

[60] Nicolosi R., Bell S.J., Bistrian B.R., Greenberg I., Forse R.A., Blackburn G.K. Plasma lipid changes after supplementation with $\beta$-glucan fiber from yeast. Am. J. Clin. Nut. 1999;(70) 208-12.

[61] Blagović B., Rupčić J., Mesarić M., Georgiú K., Marić V. Lipid Composition of Brewer's Yeast. Food Technol. Biotechnol. 2001;39(3) 175-81

[62] Blaut M. Relationship of prebiotics and food to intestinal microflora. Eur. J. Nutr. 2002;41(S) 11-16.

[63] Andersson M., Ellegård L., Andersson, H. Oat bran stimulates bile acid synthesis within $8 \mathrm{~h}$ as measured by $7 \alpha$-hydroxy-4-cholesten-3-one. Am. J. Clin. Nutr. 2002;76(5) 1111-16.

[64] Kahlon T.S., Woodruff C.L. In vitro Binding of Bile Acids by Rice Bran, Oat Bran, Barley and $\beta$-Glucan Enriched Barley. Cereal Chem. 2003;80(3) 260-63.

[65] Wang X., Gibson G.R. Effects of the in vitro fermentation of oligofructosenand inulin by bacteria growing in the human large intestine. J. Appl. Bacteriol. 1993;75 373-80.

[66] Wolever T.M.S., Brighenti F., Royall D. Effect of rectal infusion of short chain fatty acids in human subjects. Am. J. Gastroenterd.1990;84 1027.

[67] Wright R.S., Anderson J.W., Bridges S.R. Priopionate inhibits hepatocyte lipid synthesis. Proc. Soc. Exp. Biol. Med. 1990;195 26.

[68] Luo J., Rizkalla S.W., Alamowitch C. Chronic consumption of short-chain fructooligosaccharides by healthy subjects decreased basal hepatic glucose production but had no effect on insulin-stimulated glucose metabolism. Am. J. Clin. Nutr. 1996;(63) 939-45.

[69] Canzi, E., Guglielmetti, S., Mora, D., Tamagnini, I. and Parini, C. Conditions affecting cell surface properties of human intestinal bifidobacteria. Antonie van Leeuwenhoek. 2005;(88) 207-19.

[70] Rumsey G.L., Winfree R.A., Hughes S.G., Nutritional values of dietary nucleic acids and purine bases to rainbow trout. Aquaculture. 1992;108 97-110.

[71] Oliva-Teles A., Goncalves P. Partial replacement of fishmeal by brewers yeast Saccaromyces cerevisae in diets for sea bass Dicentrarchus labrax juveniles, Aquaculture. 2001;202 269-78.

[72] Yoshida Y., Yokoi W., Wada Y., Ohishi K., Ito M., Sawada H. Potent hypocholesterolemic activity of the yeast Kluyveromyces marxianus YIT 8292 in rats fed a high cholesterol diet. Biosci. Biotechnol. Biochem. 2004;68 1185-92. 